\title{
Simulation systems for tsunami wave propagation forecasting within the French tsunami warning center
}

\author{
A. Gailler, H. Hébert, A. Loevenbruck, and B. Hernandez
}

CEA, DAM, DIF, 91297 Arpajon, France

Correspondence to: A. Gailler (audrey.gailler@cea.fr)

Received: 28 November 2012 - Published in Nat. Hazards Earth Syst. Sci. Discuss.: Revised: 17 May 2013 - Accepted: 23 May 2013 - Published: 9 October 2013

\begin{abstract}
A model-based tsunami prediction system has been developed as part of the French Tsunami Warning Center (operational since 1 July 2012). It involves a precomputed unit source functions database (i.e., a number of tsunami model runs that are calculated ahead of time and stored). For the Mediterranean basin, the faults of the unit functions are placed adjacent to each other, following the discretization of the main seismogenic faults. An automated composite scenarios calculation tool is implemented to allow the simulation of any tsunami propagation scenario (i.e., of any seismic moment). Uncertainty on the magnitude of the detected event and inaccuracy of the epicenter location are taken into account in the composite scenarios calculation. Together with this forecasting system, another operational tool based on real time computing is implemented as part of the French Tsunami Warning Center. This second tsunami simulation tool takes advantage of multiprocessor approaches and more realistic seismological parameters, once the focal mechanism is established. Three examples of historical earthquakes are presented, providing warning refinement compared to the rough tsunami risk map given by the model-based decision matrix.
\end{abstract}

\section{Introduction}

Improvements in the availability of sea-level observations and advances in numerical modeling techniques are increasing the potential for tsunami warnings to be based on numerical model forecasts. Numerical tsunami propagation and inundation models are well developed, but they present a challenge to run in real time, partly due to computational limitations and also a lack of detailed knowledge on the earthquake rupture parameters.

Within the framework of the French Tsunami Warning Center (FTWC) that has been operational since 1 July 2012, these numerical methods are adapted to contribute to future operational tools to quickly provide, in particular, a map with uncertainties showing zones in the main axis of energy at the Mediterranean and NE Atlantic scales (i.e., deep ocean). For this purpose, a strategy based on a precomputed tsunami unit source functions database is developed, as source parameters available a short time after an earthquake occurs are preliminary and may be somewhat inaccurate. Existing numerical models are good enough to provide a useful guidance for warning structures to be quickly disseminated. When an event occurs, an appropriate variety of offshore tsunami propagation composite scenarios may be recalled by combining precomputed propagation solutions (single- or multisources) through an automatic interface (the precomputed propagation solutions being stored as a database of unit source functions). This approach is intended to provide quick estimates of tsunami offshore propagation, and help hazard assessment and evacuation decision-making.

As numerical model accuracy is inherently limited by errors in bathymetry and topography, and as inundation maps calculation is more complex and expensive in terms of computational time, only tsunami offshore propagation modeling is included in the forecasting database. Far-field solutions for moderate earthquakes are less sensitive to spatiotemporal details of the source (they depend primarily on the magnitude and location of the epicenter), and allow using a single sparse bathymetric computation grid for the numerical modeling. Moreover, working with deep ocean propagation modeling enables application of only the properties of the linearity 


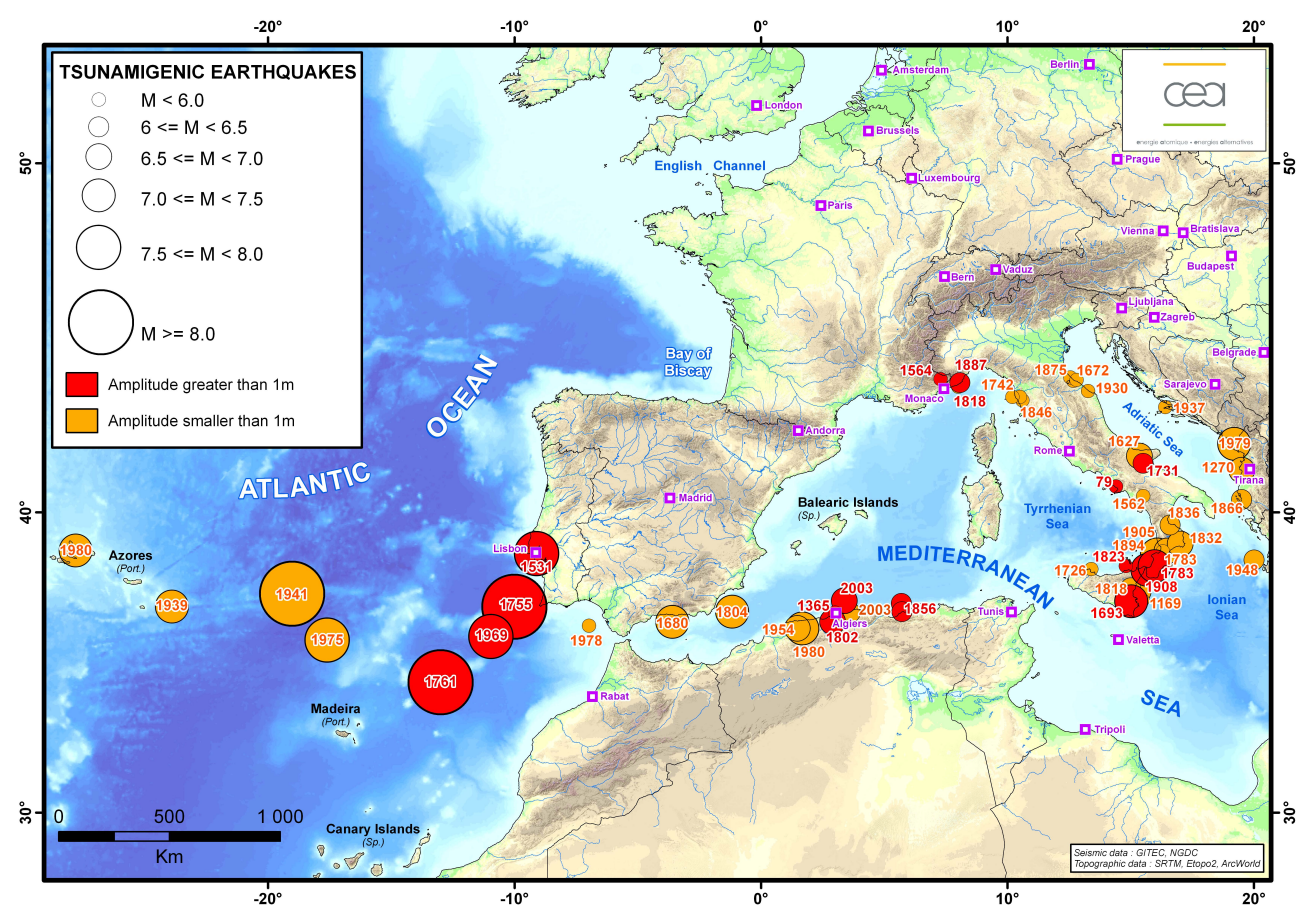

Fig. 1. Historical tsunamigenic seismicity in western Mediterranean and northeast Atlantic.

of the physics of tsunami generation and propagation in the ocean (because amplitudes are very small compared to the wavelength). But a database of precomputed results cannot contain all possible tsunami events because of too much variability in the mechanism of tsunamigenic earthquakes. In principle, an infinite number of tsunami propagation scenarios can be constructed by linear combinations of a finite number of precomputed "basis" scenarios. Such a conservative approach is chosen, selecting the scenario - or interpolation between several scenarios - with the higher impact. The whole notion of a precomputed forecasting database also requires a historical earthquake and tsunami database, as well as an up-to-date seismotectonic database that includes faults geometry and a zonation based on seismotectonic synthesis of source zones and tsunamigenic faults.

\section{Tsunami hazard in the western Mediterranean and northeast Atlantic basins}

The Azores-Gibraltar fracture zone (NE Atlantic basin) is the source of the largest earthquakes and tsunamis in western Europe, such as the 1969 earthquake on the Horseshoe Abyssal Plain $\left(M_{\mathrm{w}}=7.8\right)$ (Fukao, 1973) and the 1 November 1755 Lisbon earthquake (estimated $M_{\mathrm{w}}=8.5$ ) (Martins and Mendes Victor, 1990) (Fig. 1). Focal mechanisms of large earthquakes in this region show the transition from an extensional regime (strike-slip and normal dip-slip motion) near to the Azores to a compressional regime (strike-slip and inverse dip-slip motion) in the east of the Atlantic Ocean
(Gulf of Cádiz) (Zitellini et al., 2009; Stich et al., 2006). Seismic activity and moment tensor solutions of earthquakes indicate that present-day interplate collisional coupling in the area is most pronounced in western Iberia and the offshore Atlantic, marked by a NW to N-directed maximum horizontal stress (De Vicente et al., 2008). This is also reflected by the occurrence of historical and instrumental earthquakes, in particular by the recent earthquakes that occurred in 1980 $\left(M_{\mathrm{W}}=6.8\right), 1997\left(M_{\mathrm{w}}=6.2\right), 1998\left(M_{\mathrm{w}}=6.2\right)$ and 2007 $\left(M_{\mathrm{w}}=6.3, M_{\mathrm{w}}=6.1\right)$ in the Azores Islands and in 1969 $\left(M_{\mathrm{w}}=7.8\right)$ and $2007\left(M_{\mathrm{w}}=6.1\right)$ off the coast of southwestern Portugal (Bezzeghoud et al., 1998). The 1755 Lisbon earthquake was probably one of the most catastrophic events to have affected Europe. The earthquake destroyed Lisbon (seismic intensity of X-XI on the Mercalli scale) and was accompanied by an ocean-wide tsunami that struck up to the British Islands and the Lesser Antilles (e.g., Roger et al., 2010). This tsunami was locally large and destructive, especially in the Gulf of Cadiz and along the North Atlantic coasts, resulting in 60000 casualties in Portugal alone (Baptista et al., 1998).

The western Mediterranean Sea has also been historically impacted by tsunamis triggered by earthquakes (Fig. 1). However, the generated waves were more moderate and/or less documented than the ones usually reported in the eastern Mediterranean Sea (great tsunamis in Crete in $365 \mathrm{AD}$ and 1305 AD; e.g., Pirazzoli et al., 1996; Salamon et al., 2007; Shaw et al., 2008). 


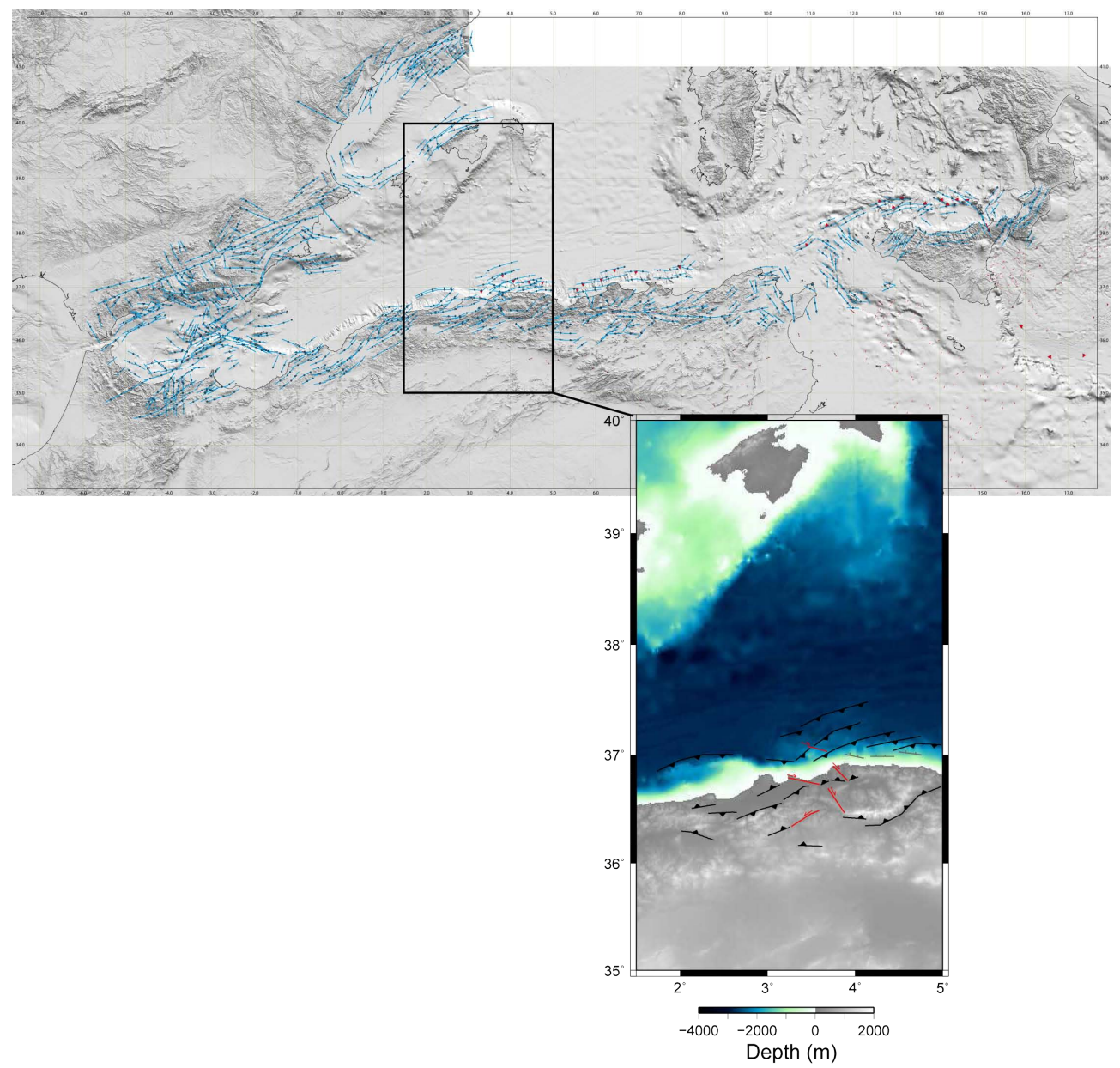

Fig. 2. Simplified fault base used to create segments of $25 \mathrm{~km}$ length representing the top edge of each $25 \times 20 \mathrm{~km}$ unit source function stored in the precomputed database (detailed view on the Boumerdès area): (black) thrust faults; (grey) normal faults; (red) strike-slip faults.

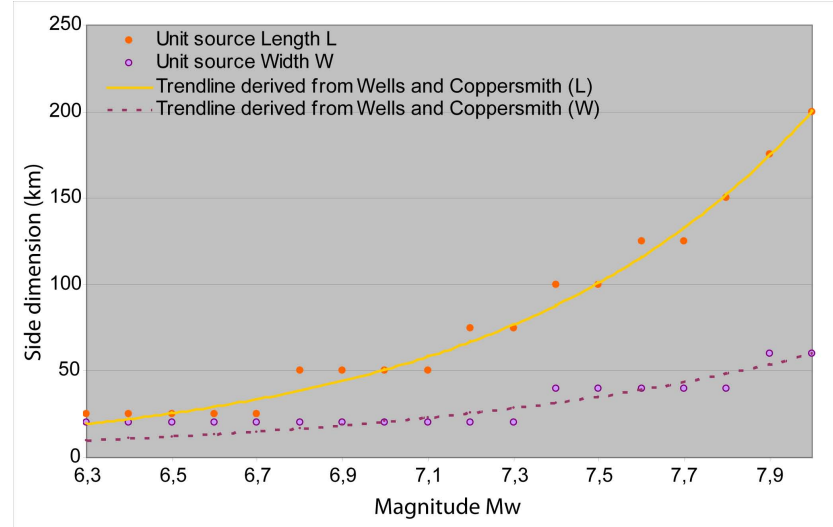

Fig. 3. Comparison of the unit source length and width involved for a given magnitude as a function of the trendlines derived from Wells and Coppersmith, 1994 (i.e., Eqs. 1 and 2).
In 1887, a strong earthquake in the Genoa Gulf, off Imperia (Italy) (magnitude 6.2 to 6.5), triggered an important tsunami that caused several floodings along the French Riviera, from Antibes to Menton (Scotti et al., 2004; Eva and Rabinovitch, 1997). In Italy, the 1908 earthquake and tsunami in the Messina Straits caused more than 60000 casualties and in present-day offers a historical reference for southern Italy (e.g., Tinti et al., 1999). The North Algerian seismically active margin hosts several possibilities of strong submarine earthquakes able to produce important tsunamis in the western Mediterranean Sea (Kherroubi et al., 2009), and the key recent event that recalled earthquake-induced tsunami awareness in the area occurred in May 2003, after the Boumerdès-Zemmouri earthquake (magnitude 6.9) in Algeria, which caused great damage and about 2000 casualties in the epicentral region (Ayadi et al., 2003; Bounif et al., 2004).

The 2003 earthquake fault, even though characterized by a moderate magnitude as far as tsunami triggering is concerned (the tsunami threshold is close to magnitude 6.3 to 6.5 ), 


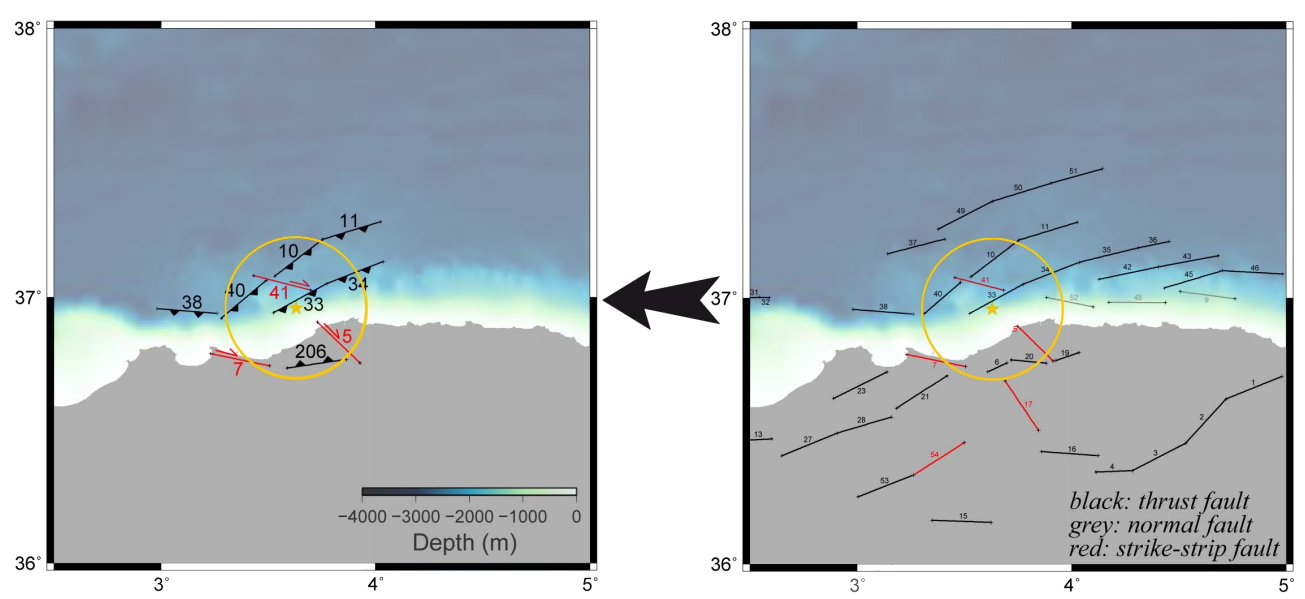

Fig. 4. Detailed view on the 2003 Boumerdès earthquake and precomputed unit source functions available in the area: (yellow star) epicenter of the event; (yellow circle) inaccuracy search radius.

was however shallow and dip enough to produce a significant sea bottom deformation, which in turn triggered tsunami waves (Meghraoui et al., 2004). In Algeria, the tsunami observations were very limited, either because steep submarine slopes do not favor amplification, or because the coastal areas were simultaneously uplifted due the coseismic deformation (Yelles et al., 2004; Delouis et al., 2004), thus preventing any inundation. But $30 \mathrm{~min}$ after the earthquake, the Balearic Islands were hit by significant tsunami waves that caused important damage in several harbors, mostly to small pleasure crafts tied in various harbors in Majorca and Menorca (Hébert and Alasset, 2003). Limited inundations of piers or restaurant terraces were very locally observed, for instance along the southeastern coastline of Majorca. Other quantitative observations were available through three good quality tide gauge records in Palma (Majorca), Sant Antoni and Menorca (Ibiza), which exhibited amplitudes from 0.5 (Palma) to $1.5 \mathrm{~m}$ (Sant Antoni) (Alasset et al., 2006). Elsewhere in the western Mediterranean, the amplitudes did not exceed 10 to $60 \mathrm{~cm}$, but significant eddies and sea withdrawals were reported in several small marinas in southern France (Sahal et al., 2009).

In the following, this Algerian event is chosen as a test case example to illustrate the composite scenarios calculation strategy developed for the western Mediterranean basin within the framework of the FTWC.

\section{Composite scenarios calculation strategy for the western Mediterranean basin}

The calculation strategy is based on three main points:

- The implementation of a precomputed unit source functions database
- The unit sources aggregation method chosen to obtain composite scenarios according to the magnitude of the detected earthquake

- The inclusion of uncertainties on the earthquake parameters

\subsection{Precomputed unit source functions database}

The precomputed unit source functions database is modeled following the western Mediterranean basin seismotectonic context. The latter being rather complex, especially along the north Algerian margin, the choice was made to draw a simplified fault system discretized into unit sources corresponding to the major structural trends of the area. The unit source database was constructed, thanks to a huge bibliography synthesis based on seismicity catalogs, focal mechanisms, seismotectonic works (e.g., Pondrelli et al., 2004; Alvarez-Gomez et al., 2011), seismic reflection profiles (e.g., Deverchère et al., 2005), bathy/topo data, satellite imagery, etc., in order to propose an exhaustive geodynamic framework (extending beyond works such as Lorito et al., 2008 or Sorensen et al., 2012). Fault traces on map (Fig. 2) thus represent the top edge of the unit sources. The length $(L)$ and width $(W)$ of each unit source are set at $25 \mathrm{~km}$ and $20 \mathrm{~km}$, respectively. Values of $L$ and $W$ are defined from empirical relations linking $L$ and $W$ to the magnitude $M_{\mathrm{w}}$ (Fig. 3).

The corresponding equations are derived from Wells and Coppersmith (1994), by fixing a length of $200 \mathrm{~km}$ for a magnitude $M_{\mathrm{w}}$ of 8.0:

$$
\begin{aligned}
& M_{\mathrm{w}}=4.135+1.679 \log _{10}(L) \\
& M_{\mathrm{w}}=4.159+2.160 \log _{10}(W) .
\end{aligned}
$$

Figure 3 shows that the choice of $25 \times 20 \mathrm{~km}^{2}$ unit sources dimension correlates well with empirical trendlines derived 
from Eqs. (1) and (2), as the combination of an adequate number of close unit source functions enables one to obtain, for each value of magnitude, rupture zone sizes compatible with these relations (e.g., 2 close unit sources giving a $50 \times 25 \mathrm{~km}$ rupture area size for $M_{\mathrm{w}}=7.0$, Fig. 3).

For each unit source, a propagation scenario (wave heights) is calculated on a 2 min bathymetry grid (i.e., deep ocean modeling only), using the following other rupture zone parameters:

- $1 \mathrm{~m}$ slip (unitary)

- rake regionalized based on the local seismotectonic history (keeping the most conservative values).

The azimuth is given by the trace of the fault on surface (i.e., top edge of rupture zone). The bathymetry grid (number of cells $=1381 \times 661)$ is taken from the General Bathymetric Chart of the Oceans (GEBCO).

The numerical method used to simulate tsunami propagation from each unit source first allows for the computation of the initial seafloor perturbation responsible for the tsunami triggering. In this framework, it consists of the static elastic dislocation accounting for the coseismic deformation (Okada, 1985). Then the propagation in the deep ocean is solved through a finite difference scheme, taking into account the nonlinear terms of the depth-averaged hydrodynamical equations, hence under the nondispersive shallow water assumption (wave celerity c being simply given by $c=\sqrt{(g h)}$ where $h$ is the water depth at each grid point) (see Hébert et al. (2009) for more details on the numerical method).

Each unit source function thus precomputed and stored in the database represents a tsunami generated by a fictitious event of magnitude $M_{\mathrm{w}}=6.76\left(M_{0}=1.75 \mathrm{E}+19 \mathrm{~N} \mathrm{~m}\right)$ with a rectangular rupture zone 25 by $20 \mathrm{~km}$ in size and $1 \mathrm{~m}$ in slip. From the northwest Algerian margin towards the Messina Straits (Sicily), 500 of such unit source functions compose the precomputed propagation solutions database.

\subsection{Composite scenarios calculation}

As evoked in the previous section, the number of unit source functions involved in a composite scenario calculation varies with the magnitude of the wanted solution (Fig. 3, Table 1). For example, for a given 7.2 magnitude event, up to 3 unit sources will be combined.

Each composite scenario thus corresponds to a linear combination of $\mathrm{x}$ close unit source functions ( $x=1$ to $2 \times 8$ ), the resulting combined wave heights being multiplied by an appropriate scaling factor $F_{\mathrm{s}} . F_{\mathrm{S}}$ is defined as a function of the magnitude $M_{\mathrm{w}}$, exploiting the linearity of the physics of tsunami generation and propagation in the ocean (e.g., Titov et al., 2005). Fs calculation strategy is inspired from Greenslade et al. (2009) who provide an enhanced tsunami forecasting database for the Joint Australian Tsunami Warning Center. Considering the expression of the seismic moment $M_{0}$ as a function of earthquake rupture characteristics, i.e., $M_{0}=\mathrm{RWL} u_{0}$ (with $R$ shear modulus and $u_{0}$ slip of the rupture), any composite wave heights $H_{\text {comp }}$ from an event with seismic moment $M_{0(\mathrm{comp})}=F_{\mathrm{s}} M_{0}$ can be generated with the same rupture length and width but with a modified slip $u_{0 \text { (comp) }}=F_{\mathrm{s}} u_{0}$. From the linearity of the physics of tsunami generation and propagation in the ocean, we can further assume that the wave heights from an event generated with a slip of $F_{\mathrm{s}} u_{0}$ are $F_{\mathrm{s}}$ times the wave heights $H$ of an event with identical $L$ and $W$, but a slip of $u_{0}$ :

$H_{\text {comp }}=F_{\mathrm{s}} H$.

Then the appropriate value for $F_{\mathrm{s}}$ is derived from the relation between magnitude $M_{\mathrm{w}}$ and seismic moment $M_{0}\left[M_{\mathrm{w}}=\right.$ $\left.2 / 3\left(\log _{10} M_{0}-9.1\right)\right]$ :

$F_{\mathrm{S}}=10^{3 / 2\left(M_{\mathrm{w}}(\mathrm{comp})-M_{\mathrm{w}}\right)}$.

A summary of the scaling factors thus determined for our forecasting database is provided in Table 1 (calculation done with $R=35 \mathrm{E}+9 \mathrm{~N} \mathrm{~m}^{-2}$ ). In each case, the new composite scenario is scaled from one or the combination of several unit source functions following the best fits between rupture dimensions ( $L$ and $W$ ) and the estimated magnitude $M_{\mathrm{w}(\mathrm{comp})}$ (i.e., Eqs. 1 and 2). For example, in the case of the 2003 Boumerdès earthquake for which the magnitude was estimated at $M_{\mathrm{W}}=6.9$, the representative composite scenarios are obtained from either a single unit source function scaled by 1.61 , or the linear combination of two close unit source functions multiplied by a factor of 0.81 . In order to be as conservative as possible, the composite scenario calculations also take into account the inaccuracy of the epicenter location for the detected event (for instance, set at a $30 \mathrm{~km}$ search radius) and the uncertainty on the associated estimated magnitude. The latter is set at \pm 0.2 but this value depends on the azimuthal coverage of the operational seismic network.

\subsection{Final composite scenario construction: example from the $M_{\mathrm{w}}=6.92003$ Boumerdès event}

\subsubsection{Inaccuracy of the epicenter location: composite solutions available within a $30 \mathrm{~km}$ search radius}

As the inaccuracy of the epicenter must be taken into account, the following methodology has been chosen:

1. the first stage consists of searching automatically all the precomputed unit sources localized within a circle whose center is the estimated epicenter of the detected event and whose radius is, in this case, set to $30 \mathrm{~km}$ (but configurable). Practically the distance between the epicenter and the middle of the top edge of each unit source is used.

In the case of the 2003 Boumerdès earthquake, 7 unit source functions stored in the precomputed database 


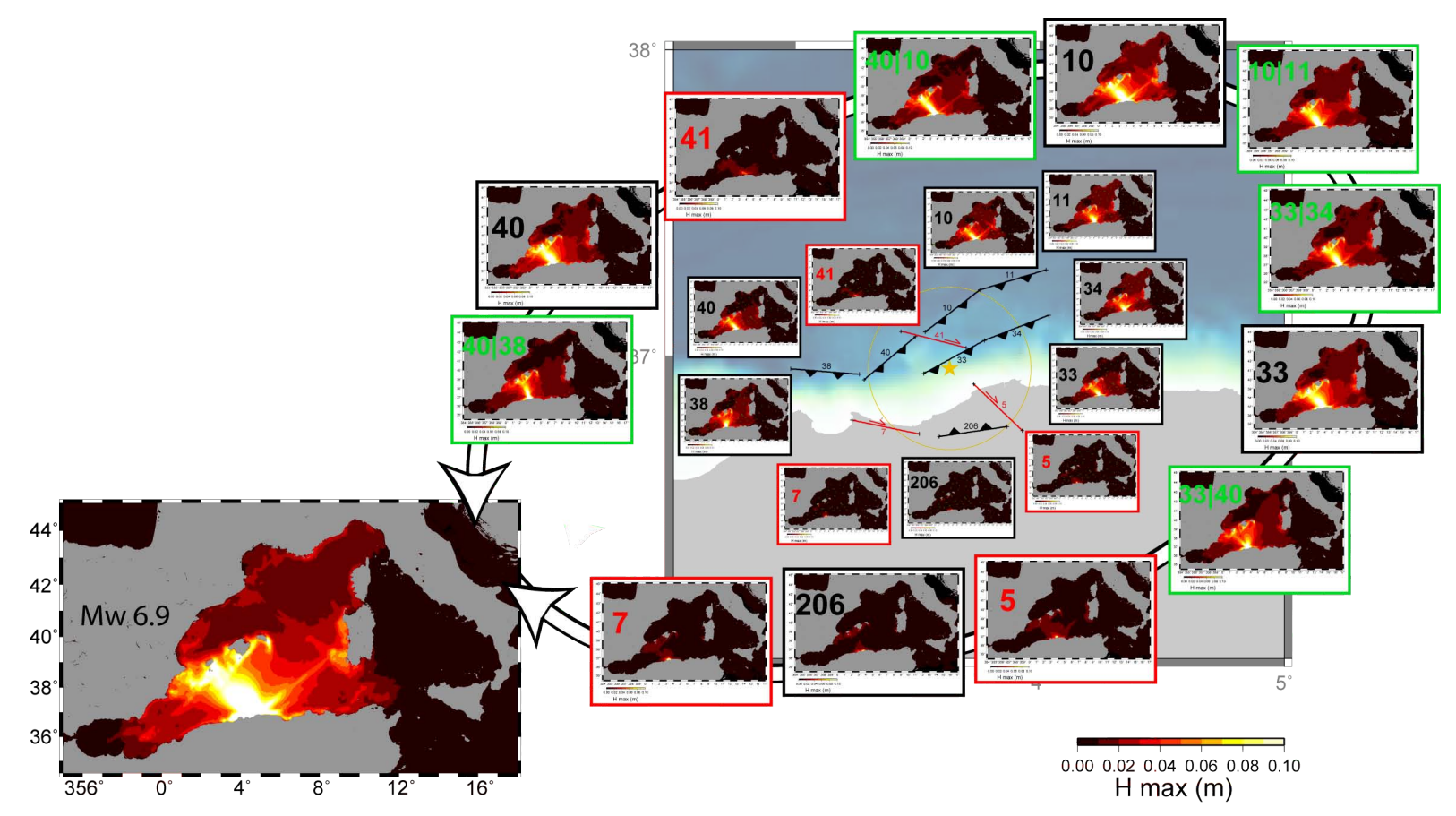

Fig. 5. Composite scenarios calculation process using the test case of the 2003 Boumerdès earthquake $\left(M_{\mathrm{W}}=6.9\right.$, Algeria). (Smallest maps) maximum wave heights stored as unit source functions $\left(M_{\mathrm{W}}=6.76\right)$ in the precomputed database and involved in this case; (medium maps) $M_{\mathrm{W}}=6.9$ derived composite scenarios solutions from a single unit source (red contour for strike-slip source and black contour for thrust source) or the combination of the two (green contour for thrust source only); (large map, left) final composite solution for $M_{\mathrm{W}}=6.9$ from all medium maps (including inaccuracy of the epicenter location).

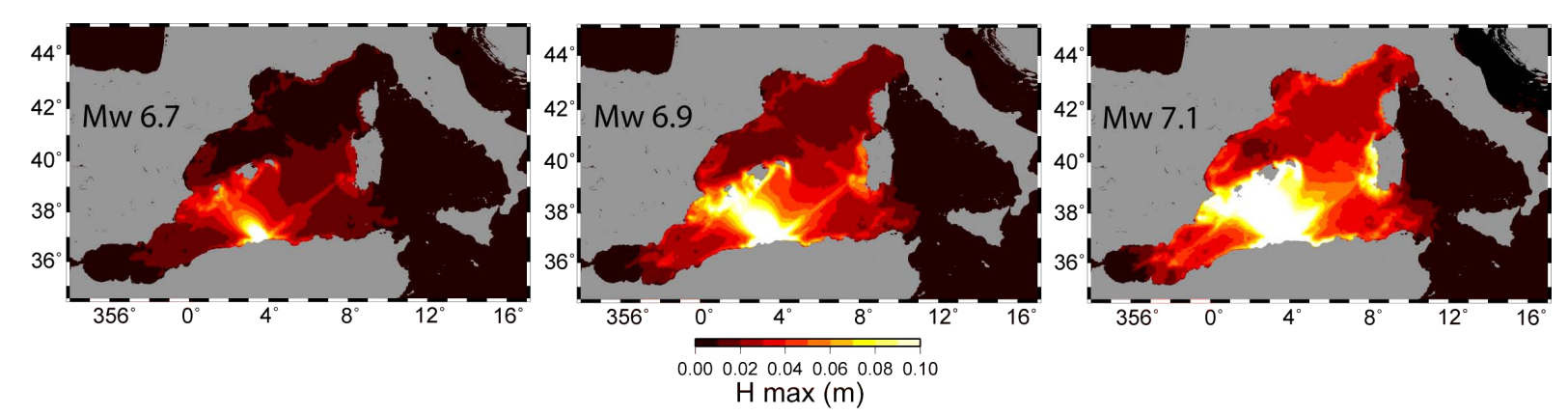

Fig. 6. Maximum wave heights obtained for the three final composite scenarios of the same event, taking into account the uncertainty on the magnitude $( \pm 0.2)$ (after $3 \mathrm{~h}$ of real time propagation).

are within the $30 \mathrm{~km}$ search radius (i.e., unit source functions number 40, 41, 10, 33, 5, 206, 7 in Fig. 4).

2. Considering an estimated magnitude of $M_{\mathrm{w}}=6.9$ for this event, 12 different possible solutions are then available, following Table 1:

- 7 solutions using the 7 single unit source functions (i.e., whose center is included in the search radius) with $F_{\mathrm{s}}=1.61$ (unit source number written above)

- 5 solutions using a linear combination of 2 close unit sources with $F_{\mathrm{s}}=0.81$ (i.e., combination of unit sources number $40+38,40+10,10+11$, $33+34$ and $33+40$, Figs. 4 and 5). In this case, at least one of the combined unit sources is part of the search radius. The other one can be taken either inside or outside the search radius, the rule being that the combination is done only on faults of the same type (thrust, normal or strike-slip) and with azimuthal and distance conditions (distance between faults centers must be in the range $18.5-37.5 \mathrm{~km}$, and maximum azimuth angle is set to $40^{\circ}$ ). 


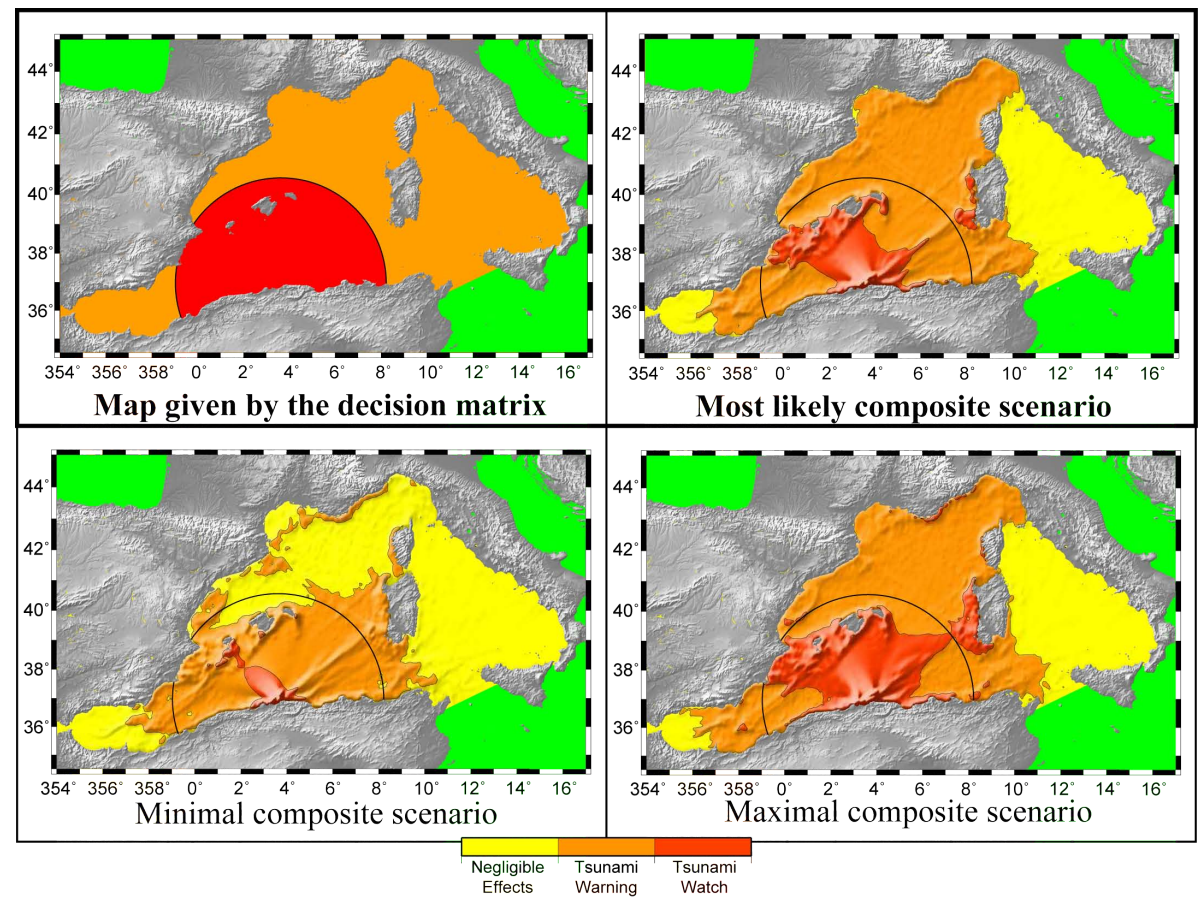

Fig. 7. Final representation produced by the forecasting system to be delivered to the authorities $8 \mathrm{~h}$ after the detection of a tsunamigenic earthquake. (black circle) $400 \mathrm{~km}$ radius warning area around the epicenter defined by the decision matrix; (green zones) area not included in the western Mediterranean basin.

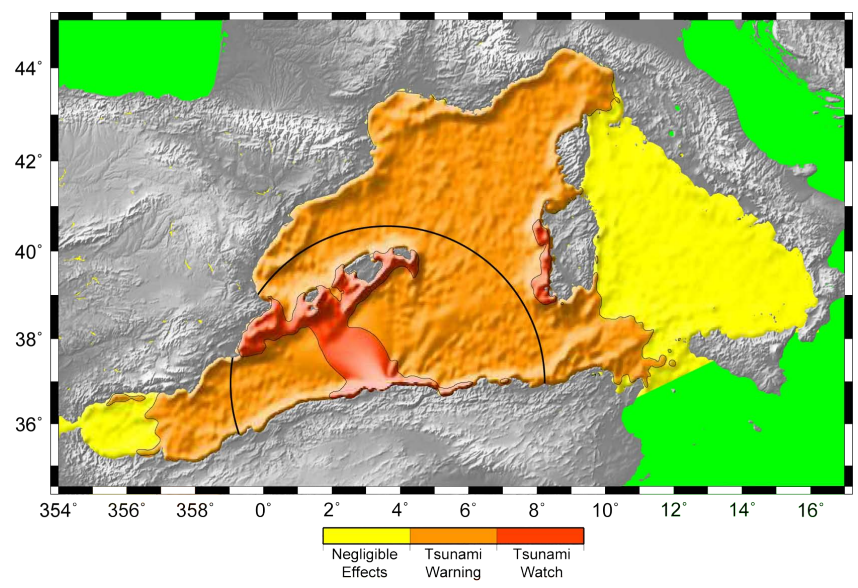

Fig. 8. Warning map resulting from the "on the fly" tsunami modeling, using the source parameters of Yelles et al. (2004). Color scale same as Fig. 7.

Note that if no unit source is found within a maximum search radius (i.e., no a priori seismotectonic information known in the considered area), the process is aborted and only the map derived from the decision matrix will be produced.

\subsubsection{Combination scheme of the maximum wave heights}

Figure 5 illustrates the automated calculation process developed to obtain the final composite scenario from the precomputed database, taking into account the inaccuracy of epicenter location (i.e., Boumerdès earthquake) for a given magnitude (i.e., $\left.M_{\mathrm{w}}=6.9\right)$. Maximum wave heights $\left(H_{\max }\right)$ are represented after $3 \mathrm{~h}$ of propagation.

The automated calculation process can be divided in 3 steps:

1. Search of the unit source functions stored in the precomputed database within a $30 \mathrm{~km}$ radius from the epicenter of the event. Smallest contoured maps in Fig. 5 represent the $H_{\max }$ for the 7 precomputed unit source functions answering this criteria and their 3 closest neighbors. Each of these propagation simulations corresponding to a fictitious magnitude of $M_{\mathrm{w}}=6.76$.

2. Composite solutions calculation as a function of the magnitude of the detected event and of the combination and scaling parameters of Table 1. Medium contoured maps show the $12 H_{\max }$ composite solutions of $M_{\mathrm{w}}=6.9$ resulting from the 10 precomputed unit source functions identified in step 1 , with conditions on the fault type and geometry as mentioned in Sect. 3.3.1. 
Table 1. Scaling factors $\left(F_{\mathrm{S}}\right)$ required to produce a composite scenario of magnitude $M_{\mathrm{w}(\mathrm{comp})}$ from the existing $25 \times 20 \mathrm{~km}{ }^{2}$ unit source functions in the western Mediterranean basin.

\begin{tabular}{|c|c|c|c|c|c|}
\hline$M_{\mathbf{w}(\operatorname{comp})}$ & $\begin{array}{l}N_{\mathrm{b}} \text { of unit } \\
\text { sources } \\
\text { involved } \\
(25 \times 20 \mathrm{~km})\end{array}$ & Length $L(\mathrm{~km})$ & Width $W(\mathrm{~km})$ & Existing $M_{\mathbf{w}}$ & $F_{\mathbf{S}}$ \\
\hline 6.5 & 1 & 25 & 20 & 6.76 & 0.40 \\
\hline 6.6 & 1 & 25 & 20 & 6.76 & 0.57 \\
\hline 6.7 & 1 & 25 & 20 & 6.76 & 0.81 \\
\hline 6.8 & 1 & 25 & 20 & 6.76 & 1.14 \\
\hline 6.8 & 2 & 50 & 20 & 6.96 & 0.57 \\
\hline 6.9 & 1 & 25 & 20 & 6.76 & 1.61 \\
\hline 6.9 & 2 & 50 & 20 & 6.96 & 0.81 \\
\hline 7.0 & 2 & 50 & 20 & 6.96 & 1.14 \\
\hline 7.1 & 2 & 50 & 20 & 6.96 & 1.61 \\
\hline 7.2 & 2 & 50 & 20 & 6.96 & 2.27 \\
\hline 7.2 & 3 & 75 & 20 & 7.08 & 1.51 \\
\hline 7.3 & 3 & 75 & 20 & 7.36 & 2.14 \\
\hline 7.3 & $2 \times 4$ & 100 & 40 & 7.08 & 0.80 \\
\hline 7.4 & 3 & 75 & 20 & 7.36 & 3.02 \\
\hline 7.4 & $2 \times 4$ & 100 & 40 & 7.08 & 1.13 \\
\hline 7.5 & $2 \times 4$ & 100 & 40 & 7.36 & 1.60 \\
\hline 7.6 & $2 \times 4$ & 100 & 40 & 7.36 & 2.26 \\
\hline 7.6 & $2 \times 4$ & 125 & 40 & 7.43 & 1.81 \\
\hline 7.7 & $2 \times 4$ & 100 & 40 & 7.36 & 3.19 \\
\hline 7.7 & $2 \times 5$ & 125 & 40 & 7.43 & 2.55 \\
\hline 7.8 & $2 \times 5$ & 125 & 40 & 7.43 & 3.61 \\
\hline 7.8 & $2 \times 6$ & 150 & 40 & 7.48 & 3.00 \\
\hline 7.9 & $2 \times 6$ & 150 & 40 & 7.48 & 4.24 \\
\hline 7.9 & $2 \times 7$ & 175 & 40 & 7.53 & 3.64 \\
\hline 8.0 & $2 \times 8$ & 200 & 40 & 7.56 & 4.50 \\
\hline
\end{tabular}

3. Final composite $H_{\max }$ calculation (large map in Fig. 5, left side) as the maximum wave heights from the 12 solutions of step 2 at each grid node. This final composite scenario corresponds to the same $M_{\mathrm{w}}=6.9$ event, including the inaccuracy of the epicenter location (being the most conservative).

\subsection{Final composite solutions with uncertainty on the magnitude}

As the source parameters available a short time after an earthquake occurs are preliminary and somewhat inaccurate, an uncertainty on the estimated magnitude of the detected event must be taken into account. Thus, the choice has been made to proceed, for $M_{\mathrm{w}}-0.2$ and $M_{\mathrm{w}}+0.2$, to the same calculation process as the one depicted in Fig. 5 and Sect. 3.3.2. That means that, for the same event, 3 final composite scenarios are produced (respectively representative of $M_{\mathrm{w}}, M_{\mathrm{w}}-0.2$ and $M_{\mathrm{w}}+0.2$ ), each one including the inaccuracy of the epicenter location.

For the 2003 Boumerdès earthquake, this implies the additional calculation for magnitudes $M_{\mathrm{w}}=6.7$ and 7.1, with corresponding combination and scaling parameters of Table 1 (Fig. 6).

The deep ocean maximum wave heights thus produced from the forecast system are then transposed into a nondimensional warning color code by a simple normalization of the $3 H_{\max }$ provided by the corresponding final composite scenarios using a fixed factor (Fig. 6). They can be interpreted as the most likely scenario and its minimal and maximal bounds, and express the tsunami warning in deep ocean, being as conservative as possible in terms of source parameters. These non-dimensional representations are produced within $5 \mathrm{~min}$ (once the first earthquake parameters are known), together with the map given by the decision matrix (with the same non-dimensional scale) (Fig. 7) and correspond to the final output of the system.

The map obtained from the decision matrix is established from the detected event magnitude and the distance between coasts and the epicenter (Table 2). It offers a rough representation of the tsunami warning at the basin scale, whether the 3 maps coming from the precomputed unit source functions database add refinement by looking at the source directivity; 


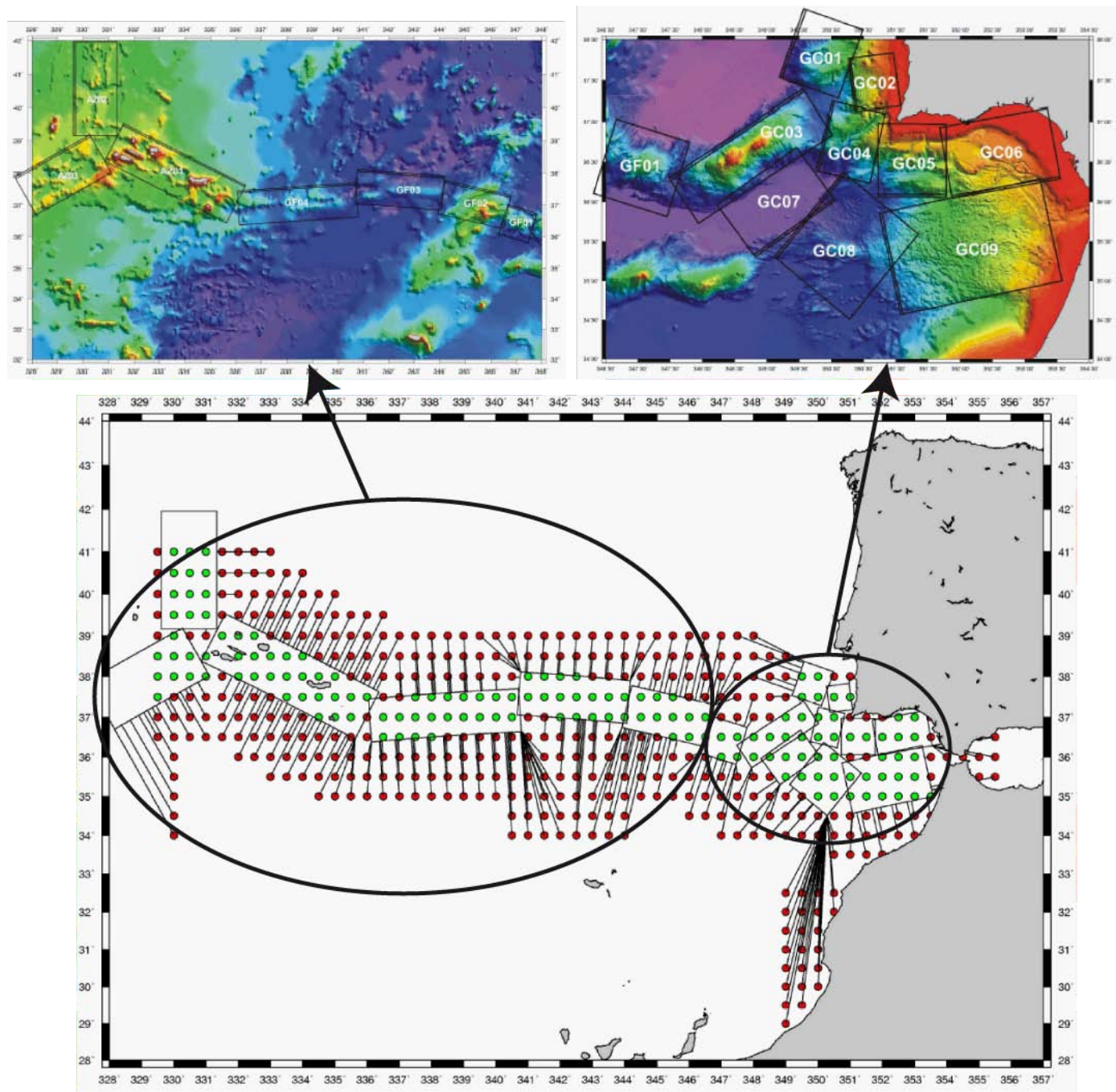

Fig. 9. Geographical location of tsunami sources and fault parameters regionalization compiled by the Joint Research Centre for Tsunami Assessment Modeling System (Annunziato, 2007) in Portugal (L. Matias, personal communication, 2010). GC, GF and AZ represent Gulf of Cadiz, Gloria Fault and Azores zones, respectively. Each dot represents the center of a source location for which 5 earthquake magnitudes scenarios are stored in the precomputed database.

Table 2. Decision matrix for the western Mediterranean and NE Atlantic basins.

\begin{tabular}{|c|c|c|c|c|c|c|c|}
\hline \multirow[t]{2}{*}{$\begin{array}{l}\text { Mediterranenean Basin } \\
\text { Depth }\end{array}$} & \multirow[t]{2}{*}{ Location } & \multirow[t]{2}{*}{$M_{\mathrm{w}}$} & \multirow[t]{2}{*}{ Tsunami Potential } & \multirow[t]{2}{*}{ Type of Bulletin } & \multicolumn{3}{|c|}{ Warning to specify } \\
\hline & & & & & Local & Regional & Basin wide \\
\hline $\begin{array}{l}<100 \mathrm{~km} \\
<100 \mathrm{~km} \\
<100 \mathrm{~km} \\
<100 \mathrm{~km} \\
>=100 \mathrm{~km}\end{array}$ & $\begin{array}{l}\text { Offshore or } D_{\mathrm{c}}<=40 \mathrm{~km} \\
{\left[D_{\mathrm{c}}=\text { distance to the coast }\right]} \\
\text { Offshore or } D_{\mathrm{c}}<=100 \mathrm{~km} \\
\text { Offshore or } D_{\mathrm{c}}<=100 \mathrm{~km} \\
\text { Offshore or } D_{\mathrm{c}}<=100 \mathrm{~km}\end{array}$ & $\begin{array}{l}5.5 \text { to } 6.0 \\
6.0 \text { to } 6.5 \\
6.5 \text { to } 7.0 \\
>=7.0 \\
>=5.5\end{array}$ & $\begin{array}{l}\text { Weak potential of local Tsunami } \\
\text { Potential of destructive local tsunami } \\
\text { Potential of destructive regional Tsunami } \\
\text { Potential of destructive Tsunami in the whole basin } \\
\text { Nil }\end{array}$ & $\begin{array}{l}\text { Information } \\
\text { Advisory } \\
\text { Watch } \\
\text { Watch } \\
\text { Information }\end{array}$ & $\begin{array}{l}\text { Advisory } \\
\text { Watch } \\
\text { Watch } \\
\text { Watch } \\
\text { Information }\end{array}$ & $\begin{array}{l}\text { Information } \\
\text { Advisory } \\
\text { Watch } \\
\text { Watch } \\
\text { Information }\end{array}$ & $\begin{array}{l}\text { Information } \\
\text { Information } \\
\text { Advisory } \\
\text { Watch } \\
\text { Information }\end{array}$ \\
\hline \multirow[t]{2}{*}{$\begin{array}{l}\text { Atlantic Basin } \\
\text { Depth }\end{array}$} & Location & $M_{\mathrm{w}}$ & Tsunami Potential & Type of Bulletin & & arning to speci & \\
\hline & & & & & Local & Regional & Basin wide \\
\hline $\begin{array}{l}<100 \mathrm{~km} \\
<100 \mathrm{~km} \\
<100 \mathrm{~km} \\
<100 \mathrm{~km} \\
<100 \mathrm{~km} \\
>=100 \mathrm{~km}\end{array}$ & $\begin{array}{l}\text { Offshore or } D_{\mathrm{c}}<=40 \mathrm{~km} \\
{\left[D_{\mathrm{c}}=\text { distance to the coast] }\right.} \\
\text { Offshore or } D_{\mathrm{c}}<=100 \mathrm{~km} \\
\text { Offshore or } D_{\mathrm{c}}<=100 \mathrm{~km} \\
\text { Offshore or } D_{\mathrm{c}}<=100 \mathrm{~km} \\
\text { Offshore or } D_{\mathrm{c}}<=100 \mathrm{~km}\end{array}$ & $\begin{array}{l}5.5 \text { to } 6.5 \\
6.5 \text { to } 7.0 \\
7.0 \text { to } 7.5 \\
7.5 \text { to } 7.9 \\
>=7.9 \\
>=5.5\end{array}$ & $\begin{array}{l}\text { Weak potential of local Tsunami } \\
\text { Potential of local Tsunami } \\
\text { Potential of destructive local tsunami } \\
\text { Potential of destructive regional Tsunami } \\
\text { Potential of destructive regional Tsunami in the whole basin } \\
\text { Nil }\end{array}$ & $\begin{array}{l}\text { Information } \\
\text { Information } \\
\text { Advisory } \\
\text { Watch } \\
\text { Watch } \\
\text { Information }\end{array}$ & $\begin{array}{l}\text { Advisory } \\
\text { Advisory } \\
\text { Watch } \\
\text { Watch } \\
\text { Watch } \\
\text { Information }\end{array}$ & $\begin{array}{l}\text { Information } \\
\text { Information } \\
\text { Advisory } \\
\text { Watch } \\
\text { Watch } \\
\text { Information }\end{array}$ & $\begin{array}{l}\text { Information } \\
\text { Information } \\
\text { Information } \\
\text { Advisory } \\
\text { Watch } \\
\text { Information }\end{array}$ \\
\hline
\end{tabular}




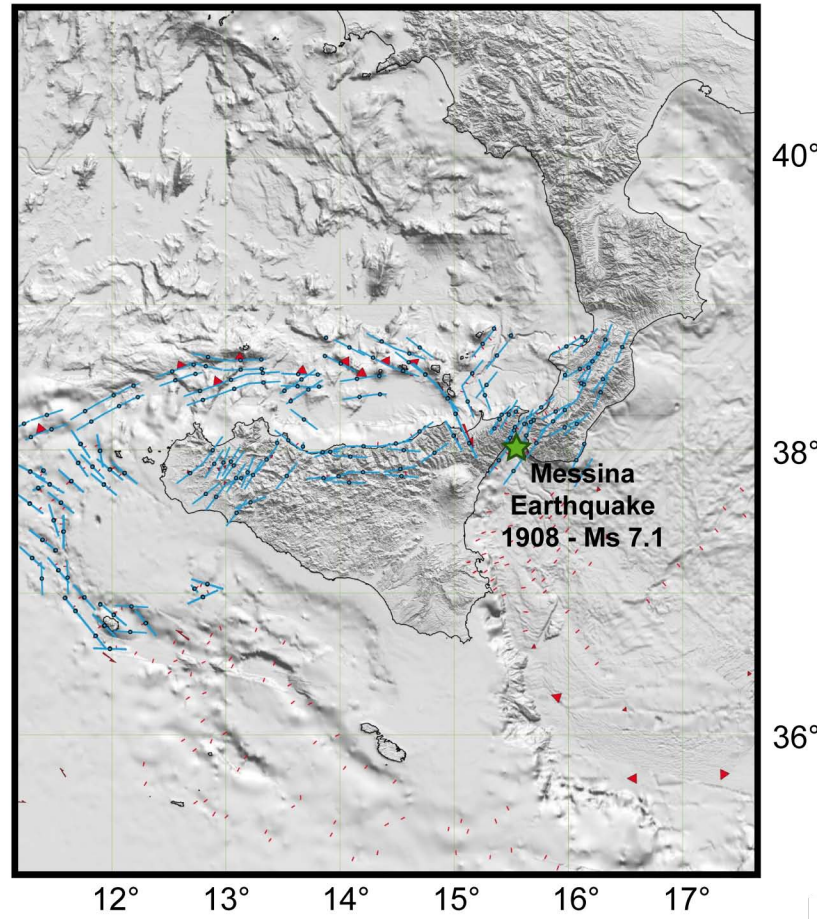

Fig. 10. Location of the epicenter of the 1908 Messina earthquake (green star), superimposed on the simplified fault base of $25 \mathrm{~km}$ length segments for the Sicily-Calabria region. Each blue segment (with a black dot in its middle) represents the top edge of each $25 \times 20 \mathrm{~km}$ unit source function stored in the precomputed database.

the main axis of tsunami energy clearly highlights more focused warning sectors.

In the case of the 2003 Boumerdès earthquake, the red zone of "tsunami watch" is defined by the decision matrix as a $400 \mathrm{~km}$ radius circle around the event epicenter. The most likely composite scenario shows a refinement of this red zone towards the Balearic coasts especially, and the western Sardinia coasts locally. Within the framework of the FTWC, the forecasting system will be triggered automatically as soon as a potential tsunamigenic event is detected.

\subsection{Comparison with "on the fly" tsunami modeling}

Together with the forecasting system, another operational tool based on real time computing is implemented as part of the French Tsunami Warning Center. This second tsunami simulation tool in deep ocean relies on the same numerical method, but takes advantage of multiprocessor approaches and more realistic seismological parameters, once the focal mechanism is established.

Both simulation systems thus provide wave heights information at the basin scale only (i.e., does not take into account the coastal response to tsunami arrival), which means evaluations against tide gage observations are unsuitable. Evaluation of the forecasting system products and the real time computing ones is done through an intercomparison between both.

In the following, calculations based on the real time computing are done using fault parameters derived from seismological studies on the considered historical events.

The coseismic deformation of the 2003 Boumerdès earthquake has been widely studied (e.g., Semmane et al., 2005; Meghraoui et al., 2004; Yelles et al., 2004), being among the largest events to occur in the western Mediterranean over the past 25 yr. For the comparison, we choose to use the source parameters proposed by Yelles et al. (2004), whose characteristics are a reverse rectangular fault plane of $32 \mathrm{~km}$ length by $14 \mathrm{~km}$ width. The azimuth, dip, rake and slip values are $\mathrm{N} 60^{\circ}, 42^{\circ} \mathrm{S}, 84^{\circ}$ and $1.8 \mathrm{~m}$, respectively. The epicenter depth is set at $8.7 \mathrm{~km}$ (i.e., rupture does not reach the surface).

Considering a shear modulus of $R=35 \mathrm{E}+9 \mathrm{~N} \mathrm{~m}^{-2}$, this source corresponds to an event of seismic moment $M_{0}=$ $2.82 \mathrm{E}+19$ N.m (i.e., $M_{\mathrm{w}}=6.9$ ). The numerical modeling is then run on the same 2 min bathymetry grid as the one used in the forecasting system, and the resulting computed maximum wave heights are transposed in the conventional nondimensional warning scale depicted previously (Fig. 8).

The warning map obtained with this "on the fly" simulation is clearly consistent with the ones derived from the precomputed database of unit source functions (Fig. 7). In terms of risk assessment, it takes place between the "minimal composite scenario" and the "most likely composite scenario", but being closer to the latter. The same tsunami watch sectors (red zones) are highlighted, i.e., Balearic coasts and western Sardinia coasts locally. This evaluation shows that the forecasting system provides coherent tsunami warning information.

\section{Composite scenarios calculation strategy for the NE Atlantic basin}

The calculation strategy is based on the three main points as for the western Mediterranean basin (see Sect. 3), the major difference being the precomputed unit source function database construction.

For the NE Atlantic basin, a definition of source parameters for the generation of tsunamis along the Azores Gibraltar plate boundary has been compiled already by the Joint Research Centre for Tsunami Assessment Modeling System (Annunziato, 2007) in Portugal (named TAT/JRC; L. Matias, personal communication, 2010). To ensure coherency between neighboring national tsunami warning centers, the same geographical locations of tsunami sources were used (e.g., Matias et al., 2013). The Azores-Gibraltar transform zone is thus divided into several boxes in which all sources have the same fault parameters (derived from the historical focal mechanisms that would generate the worst tsunami scenarios) (Fig. 9, top). The sources mesh used to create the 

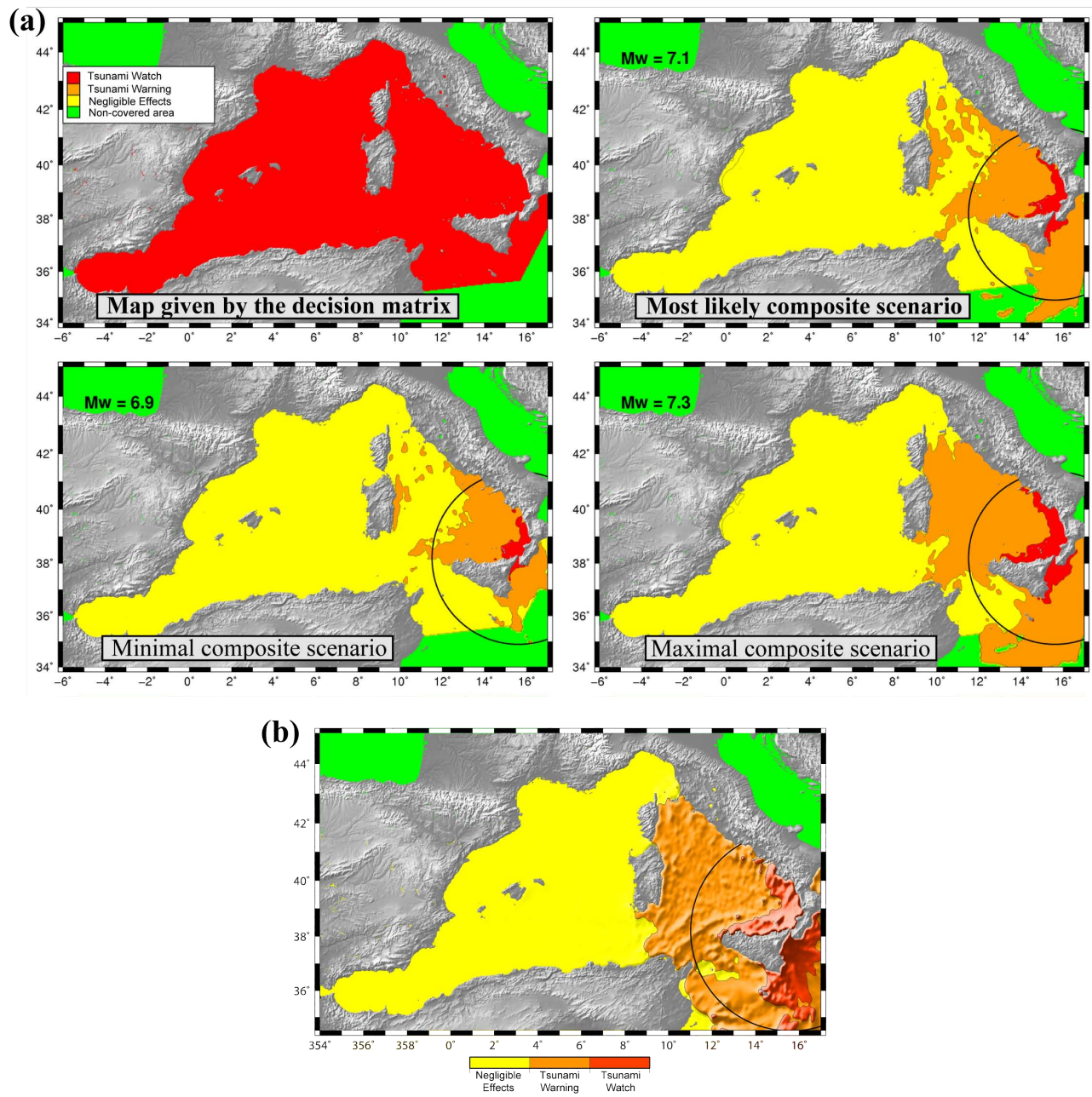

Fig. 11. (a) Result of the composite scenarios calculation process (i.e., model-based tsunami prediction system): final representation destined for the French authorities using the test case of the 1908 Messina earthquake $\left(M_{\mathrm{S}}=7.1\right.$, Sicily). Black circle: $400 \mathrm{~km}$ radius area around the epicenter (decision matrix parameter). (b) Warning map resulting from "on the fly" tsunami modeling (source parameters of Tinti et al., 1999)

precomputed unit tsunami scenarios stored for this area is shown in Fig. 9 (bottom).

Compared to the western Mediterranean database, which has 1 earthquake magnitude of $M_{\mathrm{W}}=6.76$ at each source location (see Sect. 3, Fig. 2, Table 3), the NE Atlantic scenario database has 5 earthquake magnitudes of $M_{\mathrm{w}}=6.5$, 7.0, 7.5, 8.0, and 8.5 at each source location (Table 3), all calculated over $12 \mathrm{~h}$ of real time propagation on a same $2 \mathrm{~min}$ bathymetry grid (number of cells $=3181 \times 4021)$ taken from the General Bathymetric Chart of the Oceans (GEBCO). The rupture area parameters (length, width, slip) are fixed for each magnitude and based on the parameters used by the TAT/JRC in Portugal, which were derived from empirical relationships and from historical seismicity. For the Atlantic unit sources database within the French tsunami warning center, the choice was made to favor an averaged seismogenic zone along the Azores-Gibraltar transform zone that does not exceed $55 \mathrm{~km}$ width for a 8.5 magnitude (Table 3).

When an event occurs, the wanted solution is obtained by scaling the precomputed source scenario to the closest in magnitude. The maximum wave heights given by the precomputed scenario involved are multiplied by a given scaling factor to produce the new arbitrary scenario (Table 4).

Uncertainty on the magnitude and inaccuracy of the epicenter location are taken into account the same way as for the western Mediterranean basin: 


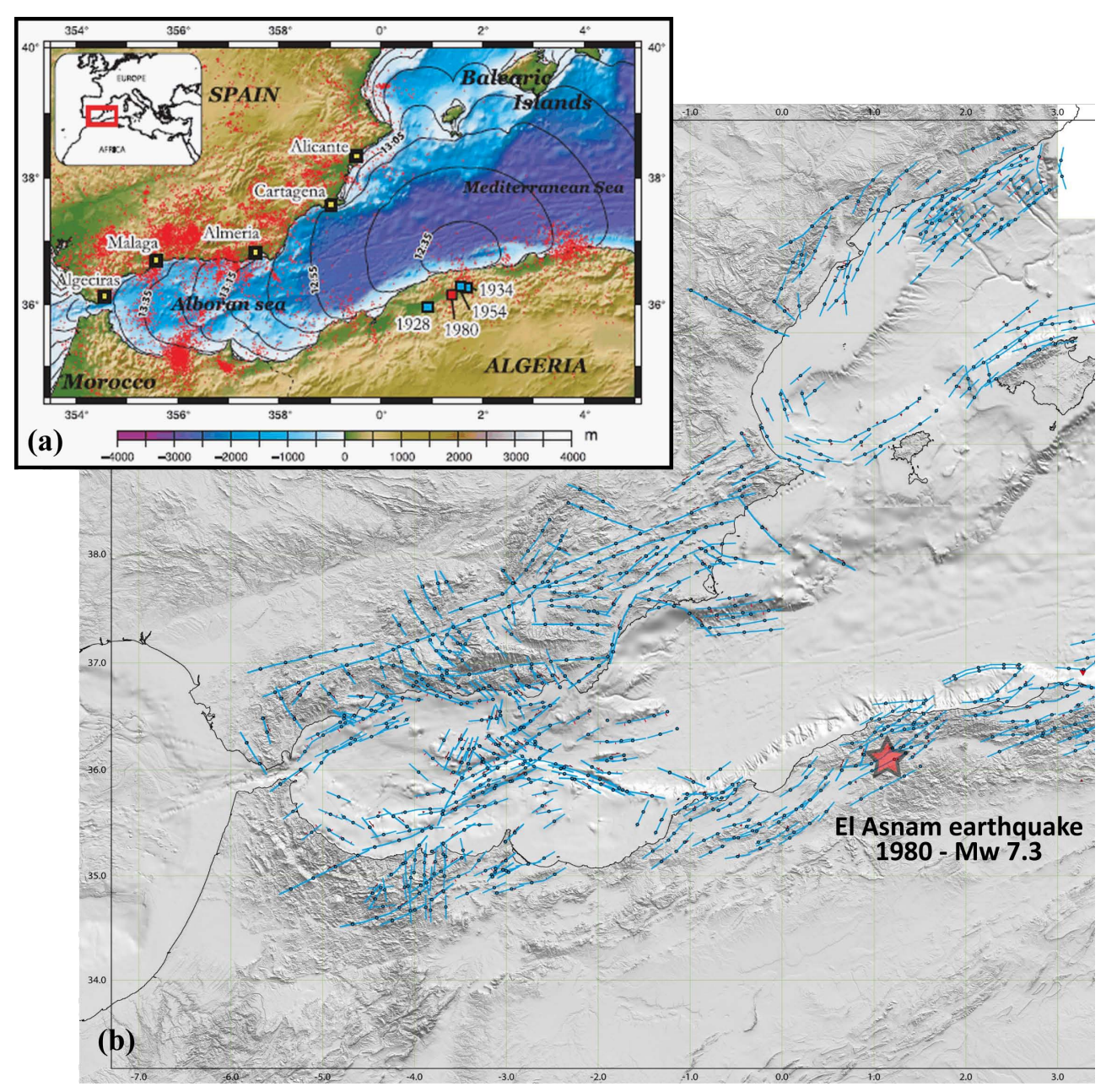

Fig. 12. (a) Location of the epicenter of the El Asnam earthquake of 10 October 1980 (red square), from Roger et al. (2011). (yellow squares) tide gauges that recorded the tsunami; (red dots) local seismicity (USGS data, 1973 to present); (solid black curves) theoretical tsunami travel times for a source located offshore El Asnam area; (blue squares) 1954 Orleansville earthquake and 1928 and 1934 events. (b) Simplified fault base of $25 \mathrm{~km}$ length segments for the western Algerian margin, the Alboran Sea and the SE Spanish coasts. Each blue segment (with a black dot in its middle) represents the top edge of each $25 \times 20 \mathrm{~km}$ unit source function stored in the precomputed database.

Table 3. Source parameters of the scenarios stored in the pre-computed database. 1 (top) for the western Mediterranean basin: 1 earthquake magnitude of $M_{\mathrm{W}}=6.76$ at each source location (bottom) for the NE Atlantic basin: 5 earthquake magnitudes of $M_{\mathrm{W}}=6.5,7.0,7.5,8.0$, and 8.5 at 4 each source location.

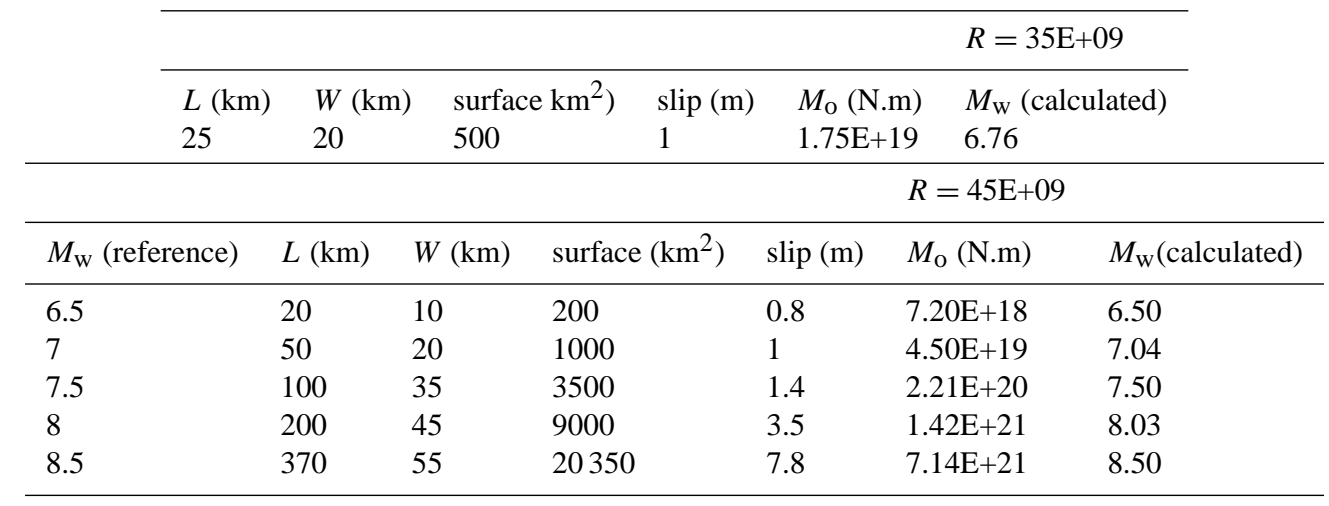




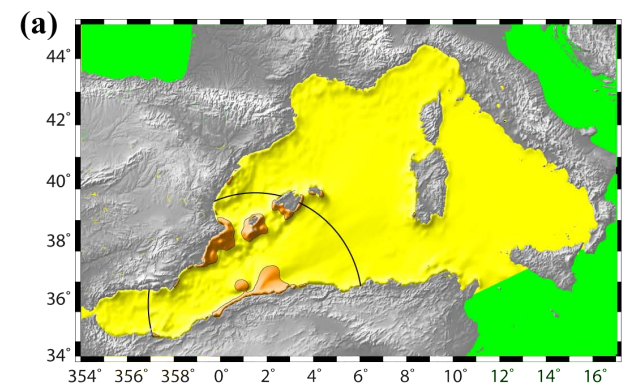

(b)

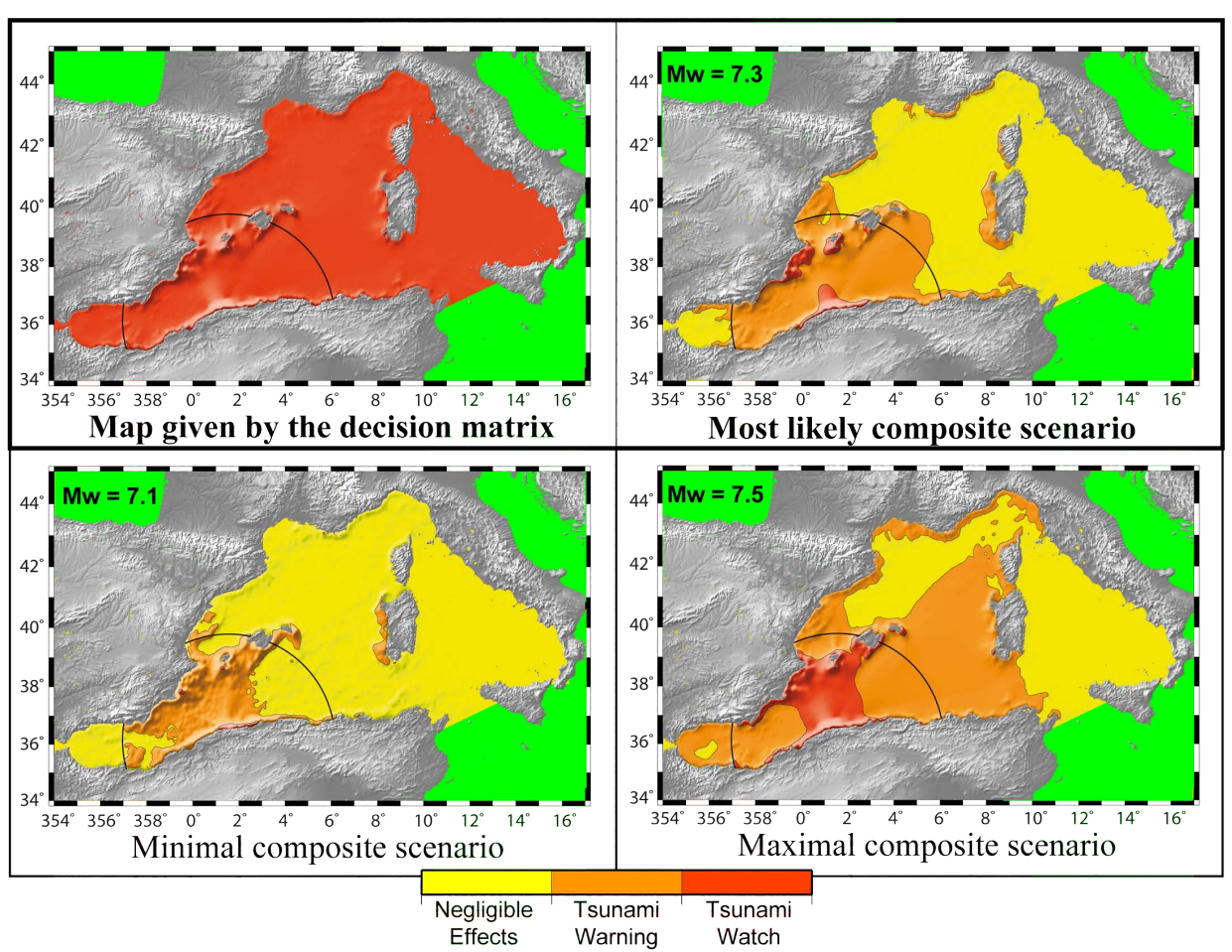

Fig. 13. (a) Warning map resulting from "on the fly" tsunami modeling using the source parameters of Roger et al. (2007) for the 1980 El Asnam earthquake $\left(M_{\mathrm{W}}=7.3\right.$, Algeria). (b) Result of the composite scenarios calculation process: final representation destined for the French authorities using the test case of the $1980 \mathrm{El}$ Asnam earthquake. Black circle: $400 \mathrm{~km}$ radius area around the epicenter (decision matrix parameter).

- for the inaccuracy of the epicenter, a search is automatically conducted of all the precomputed unit sources localized within a circle whose center is the estimated epicenter of the detected event and whose radius is, in this case, set to $30 \mathrm{~km}$ (but configurable). Each of the precomputed scenarios responding to the criteria is scaled by the appropriate factor, and the final solution corresponds to the maximum of all new arbitrary scenarios thus calculated.

- the uncertainty on the magnitude is considered through the production of 3 final composite scenarios (respectively representative of $M_{\mathrm{w}}, M_{\mathrm{w}}-0.2$ and $M_{\mathrm{w}}+0.2$ ), each one including the inaccuracy on the epicenter location.

\section{Results obtained for other historical tsunamigenic events}

\subsection{Example of the 1908 Messina earthquake $\left(M_{\mathrm{S}}=7.1\right.$, Sicily $)$}

The Messina (Sicily) earthquake of 1908, with an estimated seismic moment of $M_{\mathrm{o}}=5.10^{19} \mathrm{~N} \mathrm{~m}$, is the largest event to have hit the Italian coasts during the last century (e.g., Tinti et al., 1999; Amoruso et al., 2002, 2006). An estimated total of 60000 people were killed and extensive damage was recorded in Sicily and Calabria. The earthquake was followed by a tsunami that started with a large withdrawal along the whole Messina Straits. Then a flooding of the coast was observed in some villages with maximum run-up of up to $12 \mathrm{~m}$. Three main negative waves and subsequent inundation 


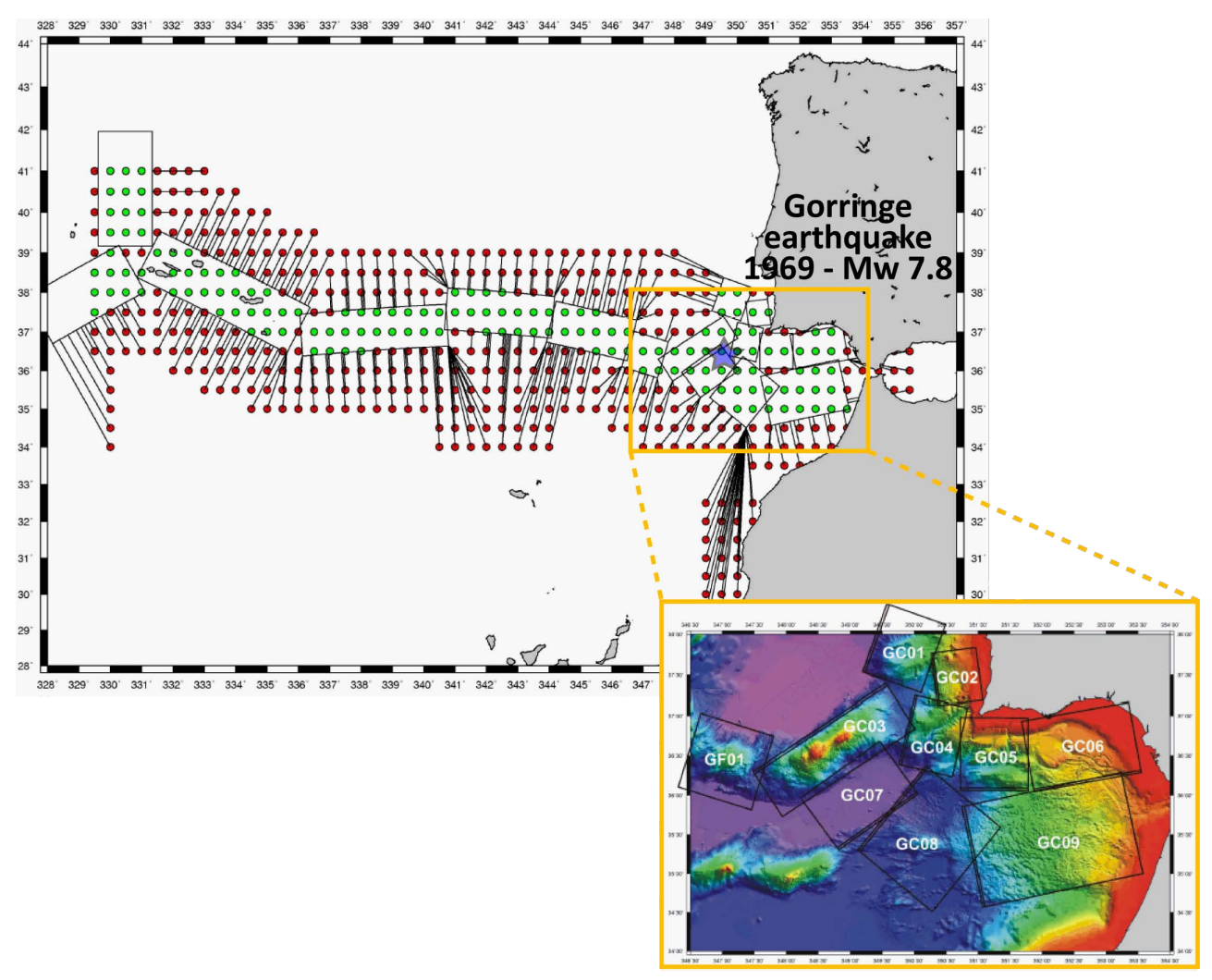

Fig. 14. Location of the 1969 Gorringe earthquake (blue star) superimposed on the simplified source location for the precomputed tsunami scenarios along the Azores-Gibraltar transform zone, taken from the TAT/JRC source definition in this area (L. Matias, personal communication, 2010)

were reported in many places, and the water waves entered $200 \mathrm{~m}$ inland locally (Platania, 1909).

The simplified fault network ( $25 \mathrm{~km}$ length segments) used to create the precomputed unit tsunami scenarios stored for this area is shown in Fig. 10 (derived from the seismotectonic context of the area). Each unit source functions in the database corresponds to a tsunami propagation solution over $3 \mathrm{~h}$ of real time propagation triggered by a $M_{\mathrm{o}}=1.75 \mathrm{E}+19 \mathrm{Nm}$ earthquake. The composite scenarios calculation tool is run with uncertainties of \pm 0.2 on the magnitude of the event and a $30 \mathrm{~km}$ radius for uncertainties of the epicenter location. Following the adopted scaling strategy (Table 1), the calculation is done thusly:

- for magnitude 7.1 (most likely composite scenario) with combinations of 2 unit source functions multiplied by $F_{\mathrm{S}}=1.61$

- for magnitude 6.9 (minimal composite scenario) with both 1 unit source function multiplied by $F_{\mathrm{s}}=1.81$, and combinations of 2 unit source functions multiplied by $F_{\mathrm{s}}=0.81$

- for magnitude 7.3 (maximal composite scenario) with both combinations of 3 unit source functions multiplied by $F_{\mathrm{s}}=2.14$, and combinations of $2 \times 4$ unit source functions multiplied by $F_{\mathrm{s}}=0.80$

The final mosaic representation is depicted in Fig. 11a. The different maps of the tsunami exposure obtained (Fig. 11a, top right and both bottom panels) bring about a refinement compared to the tsunami warning derived from the decision matrix (Fig. 11a, top left; Table 2).

Keeping in mind that even if the calculation process is chosen to be as conservative as possible, the simulation clearly illustrates that the tsunami risk is lowered compared to the information given by the decision matrix. The areas of tsunami watch are focused along the Sicilian and Calabrian coasts, and the tsunami advisory zones spread throughout the Tyrrhenian Sea up to the eastern coasts of Sardinia and Corsica.

The modeling resulting from the real time tsunami simulation tool, using Tinti et al. (1999) source parameters, is close to the maximal composite scenario obtained (Fig. 11b).

These warning maps highlight tsunami warning zones that are consistent with areas impacted by the 1908 Messina tsunami. 


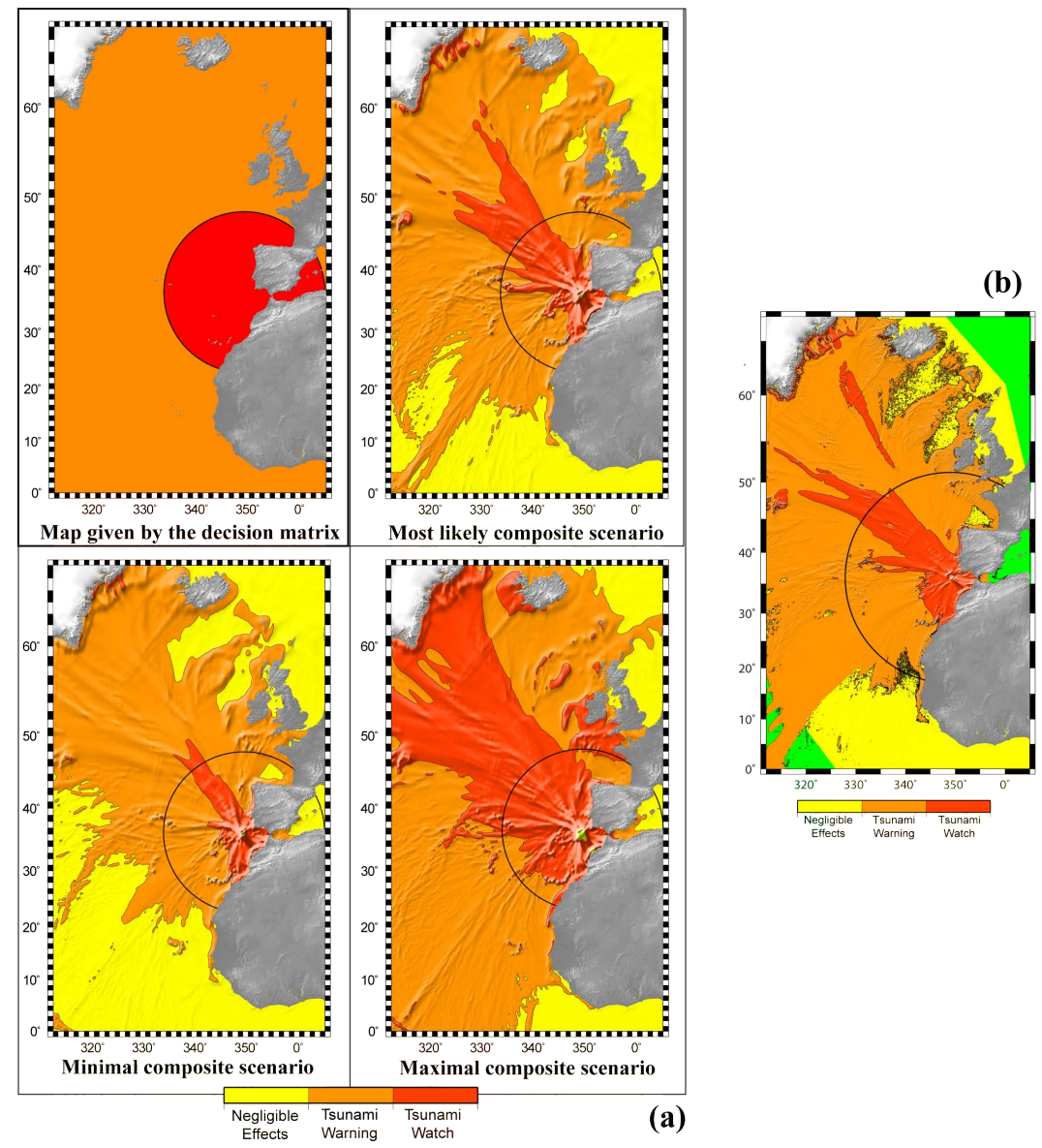

Fig. 15. (a) Result of the model-based tsunami prediction system: final representation destined for the French authorities using the test case of the 1969 Gorringe earthquake $\left(M_{\mathrm{W}}=7.8\right.$, Atlantic). Black circle: $1000 \mathrm{~km}$ radius area around the epicenter (decision matrix parameter). (b) Warning map resulting from "on the fly" tsunami modeling using the source parameters of Grandin et al. (2007).

\subsection{Example of the 1980 El Asnam earthquake $\left(M_{\mathrm{s}}=7.3\right.$, Algeria $)$}

The El Asnam (Algeria) earthquake of 10 October 1980 with an estimated magnitude $M_{\mathrm{s}}=7.3$ is one of the most destructive earthquakes recorded in northern Africa and more largely in the western Mediterranean basin. Although located inland (Fig. 12a), it is known to have been followed by a small tsunami recorded on several tide gauges along the southeastern Spanish coast (Roger et al., 2011).

The simplified fault network ( $25 \mathrm{~km}$ length segments) used to create the precomputed unit tsunami scenarios stored for this area is shown in Fig. 12b (derived from the seismotectonic context of the area). Each unit source functions in the database corresponds to a tsunami propagation solution over $3 \mathrm{~h}$ of real time propagation triggered by a $M_{\mathrm{o}}=1.75 \mathrm{E}+19 \mathrm{~N} \mathrm{~m}$ earthquake. The composite scenarios calculation tool is run with uncertainties of \pm 0.2 on the magnitude of the event and of $30 \mathrm{~km}$ radius for the epicenter location. Following the adopted scaling strategy (Table 1), the calculation is done thusly:
- for magnitude 7.3 (most likely composite scenario) with both combinations of 3 unit source functions multiplied by $F_{\mathrm{s}}=2.14$, and combinations of $2 \times 4$ unit source functions multiplied by $F_{\mathrm{s}}=0.80$

- for magnitude 7.1 (minimal composite scenario) with combinations of 2 unit source functions multiplied by $F_{\mathrm{S}}=1.61$

- for magnitude 7.5 (maximal composite scenario) with combinations of $2 \times 4$ unit source functions multiplied by $F_{\mathrm{s}}=1.60$

The final mosaic representation is depicted in Fig. 13b. The different maps of the tsunami exposure obtained (Fig. 13b, top right-bottom) bring about a refinement compared to the tsunami warning derived from the decision matrix (Fig. 13b, top left; Table 2). The modeling resulting from the real time tsunami simulation tool, using Roger et al. (2011) source parameters, is close to the minimal composite scenario obtained (Fig. 13a), due to the fact that the earthquake occurred inland. Keeping in mind that the calculation process is chosen 
Table 4. Scaling factors $\left(F_{\mathrm{S}}\right)$ required to produce a new arbitrary scenario of Magnitude $M_{\mathrm{W}}$ (comp) from the existing $M_{\mathrm{W}}=6.5,7.0$, 7.5, 8.0 and 8.5 unit source functions in the NE Atlantic basin.

\begin{tabular}{|c|c|c|}
\hline$M_{\mathrm{W}}(\operatorname{comp})$ & $M_{\mathrm{W}}(\mathrm{comp})$ & $F_{\mathrm{S}}$ \\
\hline 6.3 & 6.5 & 0.50 \\
\hline 6.4 & 6.5 & 0.71 \\
\hline 6.5 & 6.5 & 1.00 \\
\hline 6.6 & 6.5 & 1.41 \\
\hline 6.7 & 6.5 & 2.00 \\
\hline 6.8 & 7 & 0.50 \\
\hline 6.9 & 7 & 0.71 \\
\hline 7 & 7 & 1.00 \\
\hline 7.1 & 7 & 1.41 \\
\hline 7.2 & 7 & 2.00 \\
\hline 7.3 & 7.5 & 0.50 \\
\hline 7.4 & 7.5 & 0.71 \\
\hline 7.5 & 7.5 & 1.00 \\
\hline 7.6 & 7.5 & 1.41 \\
\hline 7.7 & 7.5 & 2.00 \\
\hline 7.8 & 8 & 0.50 \\
\hline 7.9 & 8 & 0.71 \\
\hline 8 & 8 & 1.00 \\
\hline 8.1 & 8 & 1.41 \\
\hline 8.2 & 8 & 2.00 \\
\hline 8.3 & 8.5 & 0.50 \\
\hline 8.4 & 8.5 & 0.71 \\
\hline 8.5 & 8.5 & 1.00 \\
\hline 8.6 & 8.5 & 1.41 \\
\hline 8.7 & 8.5 & 2.00 \\
\hline 8.8 & 8.5 & 2.82 \\
\hline 8.9 & 8.5 & 3.98 \\
\hline
\end{tabular}

as conservative as possible, the simulation clearly illustrates that although an earthquake occurs about $50 \mathrm{~km}$ inland, the tsunami risk exists. The tsunami triggered by the $1980 \mathrm{El}$ Asnam earthquake has in fact been observed in the Spanish ports located in the red area defined by our simulation: sealevel variations were recorded by the tide-gauges of Alicante, Cartagena, Almeria, Malaga and Algeciras. In Alicante, the inner breakwater mareogram showed the highest historical amplitude of oscillations (peak to trough) of $48 \mathrm{~cm}$ (Roger et al., 2011).

\subsection{Example of the 1969 Gorringe earthquake ( $M_{\mathrm{w}}=7.8$, Gorringe bank)}

The Gorringe earthquake of 28 February $1969\left(M_{\mathrm{w}} \sim 7.8\right)$ was located to the southwest of Gorringe Bank beneath the Horseshoe Abyssal Plain. It occurred on a fault without pronounced preexisting topography, although the focal mechanism showed reverse displacement with a minor strike-slip component (N35W striking fault plane with dip angle of $\sim 52^{\circ}$ ) (e.g., Grandin et al., 2007). Sea-level variations were recorded on several tide gage stations in Portugal (up to $1.14 \mathrm{~m}$ ), Morocco and Spain.
The sources mesh used to create the precomputed unit tsunami scenarios stored for this area is shown in Fig. 14. The scenarios database has 5 earthquake magnitudes $\left(M_{\mathrm{w}}=6.5\right.$, $7.0,7.5,8.0,8.5)$ at each source location, and corresponds to tsunami propagation solutions over $18 \mathrm{~h}$ of real time propagation. The composite scenarios calculation tool is run with uncertainties of \pm 0.2 on the magnitude of the event and of $30 \mathrm{~km}$ radius for the epicenter location.

Following the adopted scaling strategy (Table 4), the calculation is done thusly:

- for magnitude 7.8 (most likely composite scenario) with the $M_{\mathrm{w}}=8.0$ unit source function multiplied by $F_{\mathrm{S}}=0.50$

- for magnitude 7.6 (minimal composite scenario) with the $M_{\mathrm{w}}=7.5$ unit source function multiplied by $F_{\mathrm{s}}=$ 1.41

- for magnitude 8.0 (maximal composite scenario) with the $M_{\mathrm{w}}=8.0$ unit source function multiplied by $F_{\mathrm{s}}=$ 1.0

The final mosaic representation is depicted in Fig. 15a. The results obtained for the maps of the tsunami exposure (Fig. 15a, top right and both bottom panels) show that the watch area is globally much more stretched than the $1000 \mathrm{~km}$ area defined by the decision matrix (Fig. 15a, top left; Table 2).

The modeling resulting from the real time tsunami simulation tool, using Grandin et al. (2007) source parameters, are consistent with the model-based tsunami prediction system products, close to the most likely composite scenario obtained (Fig. 15b).

\section{Conclusions}

Improvements in the availability of sea-level observations and advances in numerical modeling techniques are increasing the potential for tsunami warnings to be based on numerical model forecasts. Numerical tsunami propagation and inundation models are well developed, but they present a challenge to run in real time, partly due to computational limitations and also due to a lack of detailed knowledge on the earthquake rupture parameters.

A first generation model-based tsunami prediction system is developed as part of the French Tsunami Warning Center, operational since mid 2012. It involves a precomputed unit source functions database (i.e., a number of tsunami model runs that are calculated ahead of time and stored). For the Mediterranean basin, the faults of the unit functions are placed adjacent to each other, following the discretization of the main seismogenic faults. An automated composite scenarios calculation tool is implemented to allow the simulation of any tsunami propagation scenario (i.e., 
of any seismic moment). Uncertainty on the magnitude of the detected event and inaccuracy of the epicenter location are taken into account in the composite scenarios calculation. For one tsunamigenic event, the tool produces 3 warning maps (i.e., most likely, minimum and maximum scenarios) together with the rough decision matrix representation. A non-dimensional coded representation is chosen to show zones in the main axis of energy at the basin scale. This forecast system provides warning refinement compared to the rough tsunami risk map given by the decision matrix.

Together with this forecasting system, another operational tool based on real time computing is implemented as part of the French Tsunami Warning Center. This second tsunami simulation tool takes advantage of multiprocessor approaches and more realistic seismological parameters, once the focal mechanism is established. Examples using 3 historical tsunamigenic earthquakes illustrate the good correlation between the results obtained and the two tools.

Acknowledgements. We thank Alain Rabaute for his work on the seismotectonic synthesis of the western Mediterranean basin and Eric Thauvin for his help and support on GIS data and software.

Edited by: M. Gonzalez Rodríguez

Reviewed by: J. A. Alvarez and Í. Aniel-Quiroga Zorrilla

\section{References}

Alasset, P. J., Hébert, H., Calbini, V., Maouche, S., and Meghraoui, M.: The tsunami induced by the 2003 Zemmouri earthquake $\left(M_{\mathrm{W}}=6.9\right.$, Algeria): modeling and results, G. J. Int., 166, 213226, 2006

Álvarez Gómez, J. A., Aniel-Quiroga, íñigo, González, M., Olabarrieta, M., and Carreño, E.: Scenarios for earthquake-generated tsunamis on a complex tectonic area of diffuse deformation and low velocity: The Alboran Sea, Western Mediterranean, Mar. Geol., 284, 55-73, 2011.

Amoruso, A., Crescentini, L., and Scarpa, R.: Source parameters of the 1908 Messina Straits, Italy, earthquake fron geodetic and seismic data, J. Geophys. Res., 107, doi:10.1029/2001JB000434, ESE 4-1-ESE 4-11, 2002.

Amoruso, A., Crescentini, L., Neri, G., Orecchio, B., and Scarpa, R.: Spatial relation between the 1908 Messina Straits earthquake slip and recent earthquake distribution, Geophys. Res. Lett., 33, L17309, doi:10.1029/2006GL027227, 2006.

Annunziato, A.: The Tsunami Assessment Modelling System by the Joint Research Centre, Sci. Tsunami Hazards, 26, 70 pp., 2007.

Ayadi, A., Maouche, S., Harbi, A., Meghraoui, M., Beldjoudi, H., Oussadou, F., Mahsas, A., Benouar, D., Heddar, A., Rouchiche, Y., Kherroubi, A., Frogneux, M., Lammali, K., Benhamouda, F., Sebaï, A., Bourouis, S., Alasset, P. J., Aoudia, A., Cakir, Z., Merahi, M., Nouar, O., Yelles, A., Bellik, A., Briole, P., Charade, O., Thouvenot, F., Semane, F., Ferkoul, A. Deramchi, A., and Haned, S. A.: Strong Algerian Earthquake Strikes Near Capital City The Zemmouri earthquake of May 2003, which measured $M_{\mathrm{W}}=6.8$, is among the largest recorded seismic events in North Africa in modern history, EOS, Trans. Am. geophys. Un., 84, 561-568, 2003.

Baptista, M. A., Miranda, P. M. A., Miranda, J. M., and Mendes Victor, L. : Constraints on the source of the 1755 Lisbon tsunami inferred from numerical modelling of historical data, J. Geodynam., 25, 159-174, 1998.

Bezzeghoud, M., Borges, J. F., Caldeira, B., Buforn, E., and Udias, A.: Seismic activity in the Azores region in the context of the western part of the Eurasia-Nubia plate boundary, International seminar on seismic risk and rehabilitation of stone masonry housing, 15 pp., 1998.

Bounif, A., Dorbath, C., Ayadi, A., Meghraoui, M., Beldjoudi, H., Laouami, N., Frogneux, M., Slimani, A., Alasset, P. J., Kharroubi, A., Ousadou, F., Chikh, M., Harbi, A., Larbes, S., and Maouche, S.: The 21 May 2003 Zemmouri (Algeria) earthquake Mw 6.8: relocation and aftershock sequence analysis, Geophys. Res. Lett., 31, L19606, 1-4, doi:10.1029/2004GL020586, 2004.

Delouis, B., Vallée, M., Meghraoui, M., Calais, E., Maouche, S., Lammali, K., Mahsas, A., Briole, P., Benhamouda, F., and Yelles, K.: Slip distribution of the 2003 Boumerdes-Zemmouri earthquake, Algeria, from teleseismic, GPS, and coastal uplift data, Geophys. Res. Lett., 31, L18607, doi:10.1029/2004GL020687, 2004.

Déverchère, J., Yelles, K., Domzig, A., Mercier de Lépinay, B., Bouillin, J.-P., Gaullier, V., Bracène, R., Calais, E., Savoye, B., Kherroubi, A., Le Roy, P., Pauc, H., and Dan, G.: Active thrust faulting offshore Boumerdes, Algeria, and its relations to the 2003 Mw 6. 9 earthquake, Geophys. Res. Lett., 32, L04311, doi:10.1029/2004GL021646, 2005.

De Vicente, G., Cloetingh, S., Muñoz-Martín, A., Olaiz, A., Stich, D., Vegas, R., Galindo-Zaldivar, J., and Fernandez-Lozano, J.: Inversion of moment tensor focal mechanisms for active stresses around the microcontinent Iberia: Tectonic implications, Tectonics, 27, TC1009, doi:10.1029/2004GL021646, 2008.

Eva, C. and Rabinovich, A. B.: The Febuary 23, 1887 tsunami recorded on the Ligurian coast, western Mediterranean, Geophys. Res. Lett., 24, 2211-2214, 1997.

Fukao, Y.: Thrust faulting at a lithospheric plate boundary: The Portugal earthquake of 1969, Earth Planet. Sci. Lett., 18, 205-216, 1973.

Grandin, R, Borges, J. F., Bezzeghoud, M., Caldeira, B., and Carrilho, F.: Simulations of strong ground motion in SW Iberia for the 1969 February $28\left(M_{\mathrm{S}}=8.0\right)$ and the 1755 November 1 $(M \sim 8.5)$ earthquakes - II. Strong ground motion simulations, Geophys. J. Int., 171, 816-822, 2007.

Greenslade, D. J. M., Simanjuntak, M. A., and Stewart, C. R. A.: An enhanced tsunami scenario database: T2, Centre for Australian Weather and Climate Research (CAWCR), CAWCR Technical Report, 14, 2009.

Hébert, H. and Alasset, P-.J.: The tsunami triggered by the 21 May 2003 Algiers earthquake, CSEM/EMSC Newsletter, 20, 10-12, 2003.

Hébert, H., Reymond, D., Krien, Y., Vergoz, J., Schindelé, F., Roger, J., and Loevenbruck, A.: The 15th August 2007 Peru earthquake and tsunami: influence of the source characteristics on the tsunami heights, Pure Appl. Geophys., 166, 1-22, 2009.

Kherroubi, A., Deverchère, J., Yelles, A., Mercier de Lépinay, B., Domzig, A., Cattaneo, A., Bracène, R., Gaullier, V., and Graindorge, D.: Recent and active deformation pattern off the east- 
ernmost Algerian margin, Western Mediterranean Sea: New evidence for contractional tectonic reactivation, Mar. Geol., 261, 17-32, 2009.

Lorito, S., Tiberti, M. M., Basili, R., Piatanesi, A., and Valensise, G.: Earthquake generated tsunamis in the Mediterranean Sea: Scenarios of potential threats to Southern Italy, J. Geophys. Res., 113, B01301, doi:10.1029/2007JB004943, 2008.

Martins, I. and Mendes Victor, L. A.: Contribução para o estudo da sismicidade de Portugal continental, Universidade de Lisboa, Instituto Geofisico do Infante D. Luis, publicacion 18, 67 pp., 1990.

Matias, L. M., Cunha, T., Annunziato, A., Baptista, M. A., and Carrilho, F.: Tsunamigenic earthquakes in the Gulf of Cadiz: fault model and recurrence, Nat. Hazards Earth Syst. Sci., 13, 1-13, doi:10.5194/nhess-13-1-2013, 2013.

Meghraoui, M., Maouche, S., Chemaa, B., Cakir, Z., Aoudia, A., Harbi, A., Alasset, P. J., Ayadi, A., Bouhadad, Y., and Benhamouda, F.: Coastal uplift and thrust faulting associated with the $M_{\mathrm{W}}=6.8$ Zemmouri (Algeria) earthquake of 21 May, 2003, Geophys. Res. Lett., 31, L19605, doi:10.1029/2004GL020466, 2004.

Okada, Y.: Surface deformation due to shear and tensile faults in a half-space, Bull. Seism. Soc. Am., 75, 1135-1154, 1985.

Pirazzoli, P. A., Laborel, J., and Stiros, S. C.: Earthquake clustering in the Eastern Mediterranean during historical times, J. Geophys. Res., 101, 6083-6097, 1996.

Platania, G.: Il maremoto dello Stretto di Messina del 28 Dicembre 1908, Boll. Sismol. Soc. It., 22, 369-458, 1909.

Pondrelli, S., Morelli, A., and Ekstrom, G.: EuropeanMediterranean regional centroid-moment tensor catalog: solutions for years 2001 and 2002, Phys. Earth Planet. Int., 145, 127-147, 2004.

Roger, J., Allgeyer, S., Hébert, H., Baptista, M. A., Loevenbruck, A., and Schindelé, F.: The 1755 Lisbon Tsunami in Guadeloupe Archipelago: Source Sensitivity and Investigation of Resonance Effects, Open Oceanogr. J., 4, 58-70, 2010.

Roger, J., Hébert, H., Ruegg, J. C., and Briole, P.: The El Asnam 1980 October 10 inland earthquake: a new hypothesis of tsunami generation, Geophys. J. Int., 185, 1135-1146, 2011.

Sahal, A., Roger, J., Allgeyer, S., Lemaire, B., Hébert, H., Schindelé, F., and Lavigne, F.: The tsunami triggered by the 21 May 2003 Boumerdés-Zemmouri (Algeria) earthquake: field investigations on the French Mediterranean coast and tsunami modelling, Nat. Hazards Earth Syst. Sci., 9, 1823-1834, doi:10.5194/nhess-9-1823-2009, 2009.
Salamon, A., Rockwell, T., Ward, S. N., Guidoboni, E., and Comastri, A.: Tsunami hazard evaluation of the Eastern Mediterranean: Historical analysis and selected modelling, Bull. Seismol. Soc. Am., 97, 705-724, 2007.

Scotti, O., Baumont D., Quenet G., and Levret, A.: The French microseismic database SISFRANCE - objectives, results and perspectives, Ann. Geophys., 47, 2-3, 571-581, 2004.

Semmane, F., Campillo, M., and Cotton, F.: Fault location and source process of the Boumerdès, Algeria, earthquake inferred from geodetic and strong motion data, Geophys. Res. Lett., 32, L01305, doi:10.1029/2004GL021268, 2005.

Shaw, B., Ambraseys, N. N., England, P. C., Floyd, M. A., Gorman, G. J., Higham, T. F. G., Jackson, J. A., Nocquet, J. M., Pain, C. C., and Piggott, M. D.: Eastern Mediterranean tectonics and tsunami hazard inferred from the AD 365 earthquake, Nature Geosci., 1, 268-276, 2008.

Sorensen, M. B., Spada, M., Babeyko, A., Wiemer, S., and Grunthal, G.: Probabilistic tsunami hazard in the Mediterranean Sea, J. Geophys. Res., 117, B01305, doi:10.1029/2010JB008169, 2012.

Stich, D., Serpelloni, E., de Lis Mancilla, F., and Morales, J.: Kinematics of the Iberia-Maghreb plate contact from seismic moment tensors and GPS observations, Tectonophysics, 426, 295-317, 2006.

Tinti, S., Armigliato, A., Bortolucci, E., and Piatanesi, A.: Identification of the Source Fault of the 1908 Messina Earthquake through Tsunami Modelling. Is it a possible task?, Phys. Chem. Earth B., 24, 417-421, 1999.

Titov, V. V., Gonzalez, F. I., Bernard, E. N., Eble, M., Mofjeld, H. O., Newman, J., and Venturato, A. J.: Real-time tsunami forecasting: Challenges and solutions, Nat. Hazards, 35, 41-58, 2005.

Wells, D. L. and Coppersmith, K. J.: New empirical relationships among magnitude, rupture length, rupture width, rupture area, and surface displacement, Bull. Seismol. Soc. Am., 84, 974$1002,1994$.

Yelles, K., Lammali, K., Mahsas, A., Calais, E., and Briole, P.: Coseismic deformation of the May 21st, 2003, $M w=6.8$ Boumerdès earthquake, Algeria, from GPS measurements, Geophys. Res. Lett., 31, L13610, doi:10.1029/2004GL019884, 2004.

Zitellini, N., Gràcia, E., Matias, L., Terrinha, P., Abreu, M., DeAlteriis, G., Henriet, J., Dañobeitia, J., Masson, D., Mulder, T., Ramella, R., Somoza, L., and Diez, S.: The quest for the AfricaEurasia plate boundary west of the Strait of Gibraltar, Earth Planet. Sci. Lett., 280, 13-50, 2009. 